\title{
$R-B P M V$-Mediated Resistance to Bean pod mottle virus in Phaseolus vulgaris L. Is Heat-Stable but Elevated Temperatures Boost Viral Infection in Susceptible Genotypes
}

\author{
Chouaïb Meziadi ${ }^{1,2}$, Julie Lintz ${ }^{1,2}$, Masoud Naderpour ${ }^{1,2,3}$, Charlotte Gautier ${ }^{1,2} \mathbb{D}^{1}$, Sophie Blanchet ${ }^{1,2}$, \\ Alicia Noly ${ }^{1,2}$, Ariane Gratias-Weill ${ }^{1,2}$, Valérie Geffroy ${ }^{1,2}$ and Stéphanie Pflieger ${ }^{1,2, *}$ \\ 1 Université Paris-Saclay, CNRS, INRAE, Univ Evry, Institute of Plant Sciences Paris-Saclay (IPS2), \\ F-91405 Orsay, France; chouaib.meziadi@corebiogenesis.com (C.M.); julie.lintz@univ-lorraine.fr (J.L.); \\ m.naderpour@areeo.ac.ir (M.N.); charlotte-gautier60@hotmail.fr (C.G.); \\ sophie.blanchet@universite-paris-saclay.fr (S.B.); alicia.noly@universite-paris-saclay.fr (A.N.); \\ ariane.gratias-weill@universite-paris-saclay.fr (A.G.-W.); valerie.geffroy@universite-paris-saclay.fr (V.G.) \\ 2 Université de Paris, CNRS, INRAE, Institute of Plant Sciences Paris-Saclay (IPS2), F-91405 Orsay, France \\ 3 Seed and Plant Certification and Registration Research Institute, Agricultural Research, \\ Education and Extension Organization, Ministry of Agriculture, Allameh Jafari Blvd, Karaj, Iran \\ * Correspondence: stephanie.pflieger@universite-paris-saclay.fr; Tel.: +33-1-69-15-33-41
}

Citation: Meziadi, C.; Lintz, J.; Naderpour, M.; Gautier, C.; Blanchet, S.; Noly, A.; Gratias-Weill, A.; Geffroy, V.; Pflieger, S. R-BPMV-Mediated Resistance to Bean pod mottle virus in Phaseolus vulgaris L. Is Heat-Stable but Elevated Temperatures Boost Viral Infection in Susceptible Genotypes. Viruses 2021, 13, 1239. https:// doi.org/10.3390/v13071239

Academic Editors: Eugene Savenkov and Katalin Nemes

Received: 8 May 2021

Accepted: 21 June 2021

Published: 26 June 2021

Publisher's Note: MDPI stays neutral with regard to jurisdictional claims in published maps and institutional affiliations.

Copyright: (C) 2021 by the authors. Licensee MDPI, Basel, Switzerland. This article is an open access article distributed under the terms and conditions of the Creative Commons Attribution (CC BY) license (https:// creativecommons.org/licenses/by/ $4.0 /)$

\begin{abstract}
In the context of climate change, elevated temperature is a major concern due to the impact on plant-pathogen interactions. Although atmospheric temperature is predicted to increase in the next century, heat waves during summer seasons have already become a current problem. Elevated temperatures strongly influence plant-virus interactions, the most drastic effect being a breakdown of plant viral resistance conferred by some major resistance genes. In this work, we focused on the $R-B P M V$ gene, a major resistance gene against Bean pod mottle virus in Phaseolus vulgaris. We inoculated different BPMV constructs in order to study the behavior of the R-BPMV-mediated resistance at normal $\left(20^{\circ} \mathrm{C}\right)$ and elevated temperatures (constant 25,30 , and $35^{\circ} \mathrm{C}$ ). Our results show that $R-B P M V$ mediates a temperature-dependent phenotype of resistance from hypersensitive reaction at $20{ }^{\circ} \mathrm{C}$ to chlorotic lesions at $35{ }^{\circ} \mathrm{C}$ in the resistant genotype BAT93. BPMV is detected in inoculated leaves but not in systemic ones, suggesting that the resistance remains heat-stable up to $35^{\circ} \mathrm{C}$. $R-B P M V$ segregates as an incompletely dominant gene in an F2 population. We also investigated the impact of elevated temperature on BPMV infection in susceptible genotypes, and our results reveal that elevated temperatures boost BPMV infection both locally and systemically in susceptible genotypes.
\end{abstract}

Keywords: Bean pod mottle virus; Phaseolus vulgaris L.; heat-stable resistance; high temperature

\section{Introduction}

Among all plant diseases, viruses account for about half of all known pathogens [1] and constitute particular entities, non-living organisms that are obligate and intra-cellular parasites that need a live host for replication. Plant viruses are biotic pathogens that cause serious epidemics in major crops with annual yield losses of more than $\$ 30$ billion [2]. No effective pesticide-based control measures are effective against viruses, so the most reliable method of plant protection is increasing plant genetic resistance [2]. Plant resistance relies on different immune responses. First, recognition of viral double-stranded RNAs is a major mechanism in antiviral plant defense [3] that induces both RNA silencing [4] and pattern-triggered immunity [5-7]. Viruses have evolved viral suppressors of these responses in order to promote their own replication [8-11]. Second, plant effector-triggered immunity (ETI) is induced by the recognition of virus effectors by resistance $(R)$ proteins mostly represented by nucleotide-binding domain leucin-rich repeat containing receptors (NLRs) [12]. NLR receptors are intracellular and encoded by dominant genes [13]. Many $R$ 
genes against viruses have been identified so far, as well as the corresponding viral-encoded effectors that are subsequently referred to as avirulence (Avr) factors [14,15]. Other types of resistances are also effective against viruses such as those controlled by quantitative trait loci [16] or 'recessive genes', the latter ones encoding mutated or truncated host factors that are hijacked by viruses in their wild type forms for their life cycle [17].

Plant resistance is strongly affected by environmental conditions, and temperature is undoubtedly one of the key parameters that have a major impact on worldwide plant production. It is well known that elevated temperatures influence plant-virus interactions, as well as the timing and severity of disease epidemics [18-20], but little is known about the associated molecular mechanisms in plant-pathogen interactions [21]. The more drastic impact of elevated temperatures is the breakdown of plant viral resistance conferred by major $R$ genes [18]. Indeed, some $R$ genes have been shown to be overcome at high temperatures, usually around $28-30^{\circ} \mathrm{C}$, allowing viral infection and spreading at the wholeplant level. This is the case for the $N$-mediated resistance that occurs only at temperatures below $28{ }^{\circ} \mathrm{C}$ in Nicotiana tabacum [22] and for the Tsw-gene-mediated resistance that is overcome between 25 and $30{ }^{\circ} \mathrm{C}$ in Capsicum species [23]. Conversely, for other $R$ genes, resistance is still efficient at temperatures above $28-30{ }^{\circ} \mathrm{C}$, such as, for example, the $R x$ mediated resistance that is not compromised against Potato virus X (PVX, Potexvirus) at temperatures up to $32{ }^{\circ} \mathrm{C}$ [24]. Alternatively, elevated temperatures may also induce more mild effects on plant resistance conferred by $R$ genes. Indeed, the resistance phenotype can be modified, meaning that local necrotic lesions such as hypersensitive reaction (HR, a form of programmed cell death [25]) can be transformed into systemic necrosis. Additionally, extreme resistance, which inhibits virus replication without apparent $H R$, can be shifted to $\mathrm{HR}$ or even to systemic necrosis at temperatures above $28-30^{\circ} \mathrm{C}$. In the absence of $R$ genes, elevated temperature was shown to promote symptom severity, systemic spreading, and replication potential of viruses [26-28]. Other studies reported contradictory results in the sense that elevated temperatures reduced viral symptoms and viral accumulation [29-31], which was hypothesized to be attributable to increased efficiency of the RNA silencing pathway at elevated temperature [32]. Therefore, predicting a general outcome for all the pathosystems may be difficult.

Common bean (Phaseolus vulgaris L.) is a major pulse crop of agronomic importance cultivated as a dry grain or fresh vegetable. Indeed, it is the most important grain legume for human consumption worldwide, especially in developing countries such as Central and South America and Southeastern Africa [33]. Common bean varieties are grown over a wide range of latitudes but optimal growth conditions need temperatures comprised between 17.5 and $23{ }^{\circ} \mathrm{C}[34,35]$. Indeed, daytime temperatures above $30{ }^{\circ} \mathrm{C}$ and nighttime temperatures above $22^{\circ} \mathrm{C}$ lead to yield losses [36,37].

In the main production areas of common bean, several viruses including Potyviruses Bean common mosaic virus (BCMV), Bean common mosaic necrosis virus (BCMNV), Bean yellow mosaic virus (BYMV), and Clover yellow vein virus (ClYVV) affect the quality and quantity of bean productions (reviewed in [38]). The well-known I locus, located at the extremity of chromosome 2, confers resistance to a large part of them. In addition to resistance against Potyviruses, resistance to Comovirus has also been positioned in the region of the $I$ locus $[39,40]$. This is the case of the $R-B P M V$ gene conferring resistance to Bean pod mottle virus (BPMV) in P. vulgaris genotype BAT93 [41].

The aim of the current study was to address several questions concerning the $R-B P M V$ mediated resistance in P. vulgaris. Does the $R-B P M V$-mediated resistance to BPMV depend on temperature? If so, at which temperature does the phenotype switch occur? What is the inheritance of the $R-B P M V$ gene? Here, we report that $R-B P M V$ induces HR lesions at $20{ }^{\circ} \mathrm{C}$. Further analysis revealed that at 25 and $30{ }^{\circ} \mathrm{C}, R-B P M V$-mediated resistance still induces HR lesions, whereas at $35^{\circ} \mathrm{C}$, local HR lesions are replaced by chlorotic lesions but resistance is not overcome at the whole-plant level. Finally, we also investigated the impact of elevated temperature on BPMV infection in a compatible context (i.e., in susceptible genotypes), and our results highlighted that rising temperature boosts BPMV infection. 


\section{Materials and Methods}

\subsection{Common Bean Material and Growing Conditions}

The following genotypes of Phaseolus vulgaris were used in this study: BAT93 (Mesoamerican breeding line), JaloEEP558, Black Valentine (both Andean landraces), and two NearIsogenic Lines for the $I$ locus [42], Black Turtle 1 (BT-1; I/I, resistant to BCMV and BCMNV) and Black Turtle 2 (BT-2; $i / i$ susceptible to BCMV and BCMNV). The inheritance of $R-B P M V$ was studied using $60 \mathrm{~F} 2$ individuals derived from a cross between BAT93 $(R-B P M V / R-$ $B P M V$, resistant to BPMV) and the Andean landrace JaloEEP558 (r-bpmv/r-bpmv, susceptible to BPMV).

Growing conditions from sowing to virus inoculation were followed as described in Pflieger et al. [41] with some modifications. Briefly, seeds were sown in soil instead of vermiculite and grown in a growth chamber at $23{ }^{\circ} \mathrm{C}$ under a $16 \mathrm{~h} \mathrm{light} / 8 \mathrm{~h}$ dark cycle and $75 \%$ relative humidity until the BPMV-inoculation stage (fully expanded primary leaf stage, 10 days post-sowing in our growth conditions). From sowing to inoculation, seedlings were watered with tap water.

\subsection{Viral Material}

An infectious BPMV cDNA clone derived from isolate IA-Di1 was provided by C. Zhang and S. Whitham (Iowa State University, Ames, IA, USA) and described previously [43]. Briefly, the infectious clone BPMV-WT contains the WT-RNA1 (on infectious plasmid 'pBPMV-IA-R1M') and the WT-RNA2 (infectious plasmid 'pBPMV-IA-V1') of BPMV [43]. We also used the GFP-tagged BPMV (BPMV-GFP, infectious plasmids 'pBPMVIA-R1M' + 'pBPMV-GFP2') [43] in which a GFP cassette was inserted in the frame between the movement protein (MP) and the large-coat protein (L-CP) coding regions and was flanked with protease recognition sites, allowing excision from the RNA2 polyprotein.

\subsection{Viral Rub-Inoculation of P. vulgaris Plants and High-Temperature Assays}

Viral rub-inoculation of $P$. vulgaris plants was performed as described previously $[41,44]$. Briefly, a viral inoculum was prepared by grinding frozen or fresh infected leaves from P. vulgaris $\mathrm{cv}$. Black Valentine with a mortar and pestle in the presence of a mock buffer (potassium phosphate buffer 0.1 M, pH 7) [44]. Mechanical inoculation was then performed on one primary leaf of a healthy plant, using carborundum as an abrasive [44]. Inoculated plants were then placed in a growth chamber either at constant $20^{\circ} \mathrm{C}$ (control temperature) or at constant 25,30 , or $35^{\circ} \mathrm{C}$ (high temperature assays) in a growth chamber Aralab (Fitoclima 1.200, Rio de Mouro, Portugal) under 75\% constant humidity at $16 / 8 \mathrm{~h}$ light/dark condition. After inoculation, plants were watered with a nutritive solution. Each experiment was reproduced at least twice.

\subsection{Cell Death Assays}

For HR assays, the leaves of 7 days post-inoculation (dpi) plants were stained with trypan blue in lactophenol solution (lactic acid:glycerol:liquid phenol:distilled water (1:1:1:1), $0.067 \% w / v$ trypan blue) in universal tubes and heated in a boiling water bath for $2 \mathrm{~min}$. After cooling, the solution was replaced with chloral hydrate $(2.5 \mathrm{~g} / \mathrm{mL})$, and samples were shaken until leaves were fully destained. For observations, the chloral hydrate was replaced with $60 \%$ glycerol.

\subsection{Detection of GFP Fluorescence in Planta}

GFP fluorescence in whole plants was detected by using a Black Ray long-wave UV lamp (high intensity 100-Watt long-wave UV lamp; UVP, Upland, CA, USA). Highermagnification fluorescence detection was performed with an epifluorescence microscope for temperature assays at 20 and $25^{\circ} \mathrm{C}$ (Leica MZ16F, Leica Microsystems GmBH, Wetzlar, Germany) equipped with a fluorescein isothiocyanate-tetramethyl rhodamine isothiacyanate multiband filter. The GFP fluorescence specter was checked using a confocal microscope (Zeiss LMS880, Carl Zeiss Microscopy GmBH, Iena, Germany). For temper- 
ature assays at $30{ }^{\circ} \mathrm{C}$, we used an Axio Zoom V16 fluorescence stereomicroscope (Carl Zeiss Microscopy GmBH, Iena, Germany). Specific GFP fluorescence was detected using a short-pass filter (excitation filter, $470 / 40 \mathrm{~nm}$; barrier filter, 525/50 nm). To detect all UVfluorescent cell components including chlorophyll and GFP, a long-pass filter (excitation filter, 572/25 nm; barrier filter, 629/62 nm) was used. Images were obtained using a digital video camera (Axiocam 506 mono) coupled to the Axio Zoom microscope.

\subsection{RNA Isolation and RT-PCR Analyses}

For BPMV RNA detection, inoculated and systemic leaves from BPMV-inoculated plants were sampled at 7 and 14 or 21 dpi, respectively. Total RNA was extracted using the NucleoSpin RNA kit (Macherey-Nagel, Hœrdt, France). RNA concentrations were determined by measuring the absorbance at $260 \mathrm{~nm}$ on a NanoDrop 8000 (Thermo Fisher Scientific, Waltham, MA, USA) and integrity was checked by electrophoresis on a $1 \%$ agarose BET gel. cDNA was synthesized from $1 \mu \mathrm{g}$ of total RNA using Reverse Transcription (RT) ImProm-II ${ }^{\mathrm{TM}}$ enzyme (Promega Corp., Madison, USA) and Oligo-dT (Promega Corp., Madison, WI, USA) according to the manufacturer's protocol and finally diluted 2.5 times in Milli-Q $\mathrm{H}_{2} \mathrm{O}$.

Semi-quantitative RT-PCR was performed on $1 \mu \mathrm{L}$ of diluted cDNA using GoTaq G2 Flexi (Promega Corp., Madison, USA) and using primers specific to BPMV RNA1, RNA2, PvUBIQUITIN (PvUBI, reference gene), and PvINSULIN-DEGRADING ENZYME $(P v I D E)$ (reference gene; primers IDE-F 5'-GCAACCAACCTTTCATCAGC-3' and IDE-R 5'-AGAAATGCCTCAACCCTTTG-3'), as described previously [41]. After either 20 cycles for primers RNA1 and RNA2 or 25 cycles for primers PvUBI and PvIDE, PCR products were analyzed by electrophoresis on a $2 \%$ agarose BET gel.

BPMV virus titer was estimated using a method based on a quantitative RT-PCR (RT-qPCR) analysis by determining the quantity of BPMV RNA1 and plant PvIDE mRNA, in four biological and three technical replicates (unless otherwise stated), in order to obtain a ratio of virus RNA to plant RNA. RT-qPCR protocol and analyses were performed as described in Richard et al. [45]. Briefly, RT-qPCR analysis was performed with a LightCycler ${ }^{\circledR}$ 96 instrument in a volume of $15 \mu \mathrm{L}$ reaction containing $2 \mu \mathrm{L}$ of diluted cDNA, each specific primer with a final concentration of $0.1 \mu \mathrm{M}, 7.5 \mu \mathrm{L}$ of SYBR Green (LightCycler ${ }^{\circledR} 480$ SYBR Green I Master, Roche), and distilled water. The program used consisted of initial denaturation at $95^{\circ} \mathrm{C}$ for $5 \mathrm{~min}$ and 50 cycles of $15 \mathrm{~s}$ of denaturation, $15 \mathrm{~s}$ of hybridization, and $15 \mathrm{~s}$ of elongation at 95,60 , and $72{ }^{\circ} \mathrm{C}$, respectively. The results were analyzed using LightCycler $^{\circledR} 96$ software version 1.1.

\section{Results}

3.1. R-BPMV-Mediated Resistance Is Associated with Local HR Lesions at $20^{\circ} \mathrm{C}$ Where BPMV Is Able to Multiply in a First Step

In previous work, we have shown that the Mesoamerican genotype BAT93 is resistant to BPMV and that resistance is controlled by a major gene, named $R-B P M V$ [41]. In order to further characterize the BAT93 resistance phenotype, we performed inoculation assays using BPMV-WT and BPMV-GFP, a BPMV construct expressing GFP as a mature protein processed from the viral RNA2 polyprotein. We observed that at 7 dpi with BPMV-WT, a large number of macroscopic HR lesions developed in the inoculated leaves of BAT93 at $20^{\circ} \mathrm{C}$, whereas mosaic symptoms were visible in JaloEEP558 and Black Valentine, two susceptible genotypes lacking the $R-B P M V$ gene (Figure 1A). Trypan blue staining assays at $7 \mathrm{dpi}$ confirmed that HR lesions contained death cells (Figure 1B), thus attesting that these cells have undergone a cell death process induced by the $R-B P M V$ gene. In order to study if BPMV can multiply in some individual cells before the establishment of HR lesions, we scanned the upper surface of BPMV-GFP-inoculated leaves of BAT93 at 4 dpi using an epifluorescence microscope. JaloEEP558 was used as a susceptible genotype. Interestingly, GFP fluorescence was detected in both BAT93 and JaloEEP558 at 4 dpi in inoculated leaves (Figure 1C). Widespread fluorescence was observed in JaloEEP558 leaves, whereas in 
BAT93, GFP fluorescence was found concentrated in a number of discrete areas that we will further call 'GFP foci' (Figure 1C). This suggests that resistance conferred by $R-B P M V$ in BAT93 allows BPMV multiplication in small cell clusters but finally restricts virus spread, putatively by blocking virus cell-to-cell movement and/or inducing programmed cell death.

A

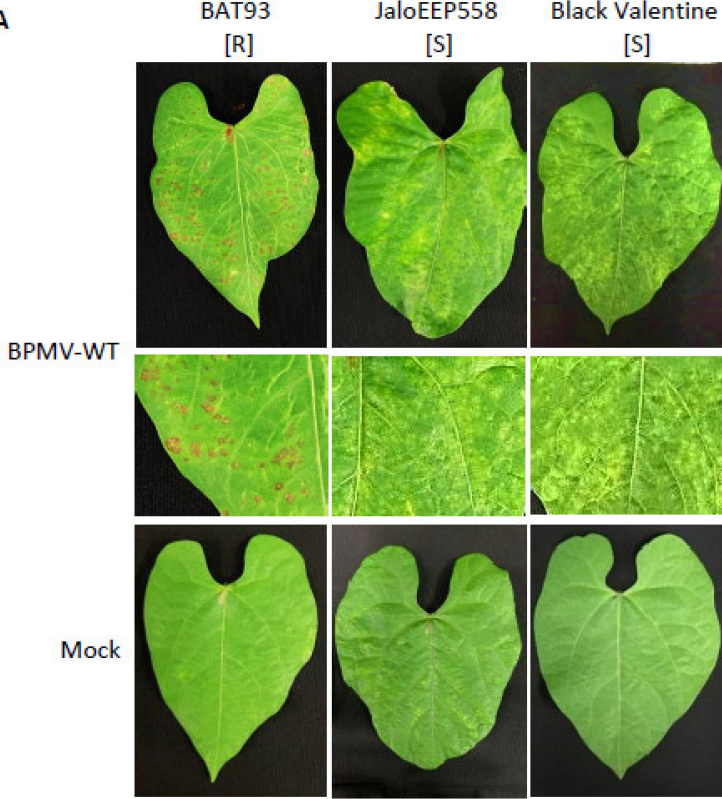

C

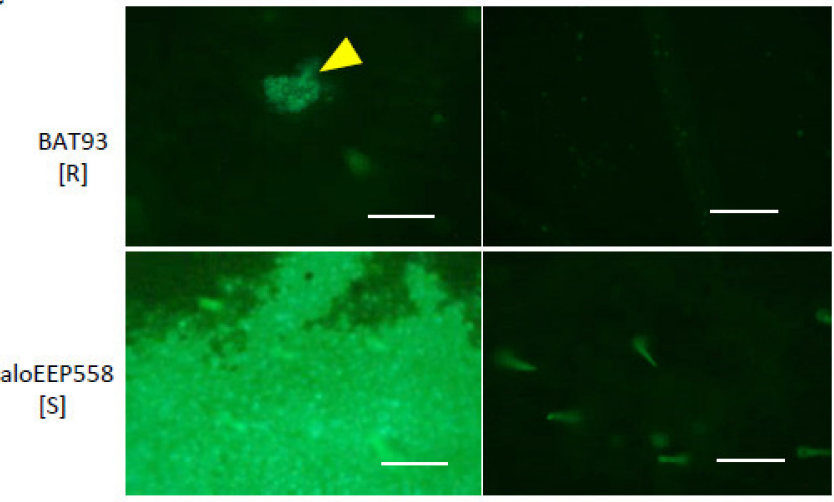

B

BAT93 + BPMV-WT
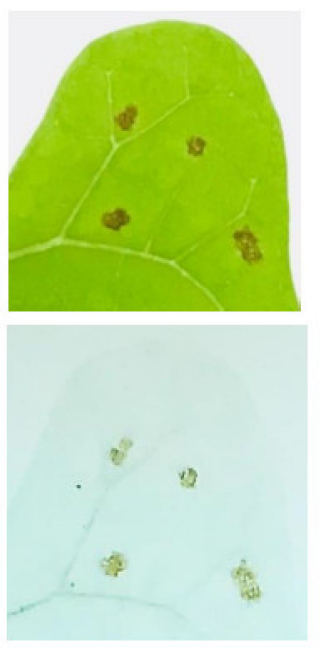

Mock

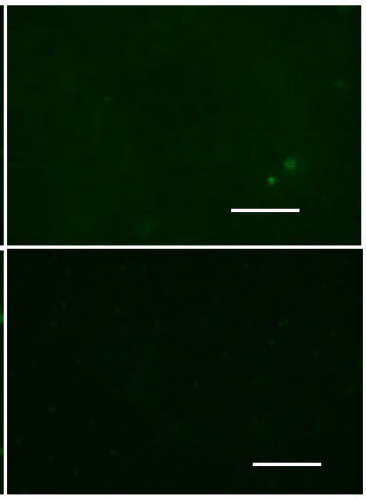

Figure 1. BPMV is able to multiply and move from cell-to-cell in the inoculated leaves of genotype BAT93 at $20{ }^{\circ} \mathrm{C}$ but infection is finally restricted by the induction of local Hypersensitive-Response (HR) lesions: (A) Representative pictures of local HR lesions on six BAT93-inoculated leaves of six different plants grown at $20{ }^{\circ} \mathrm{C}, 7$ days post-inoculation (dpi) with BPMV-WT. JaloEEP558 and Black Valentine were used as susceptible control genotypes on which mosaic/mottling symptoms are visible on the inoculated leaves at $7 \mathrm{dpi}$ with BPMV-WT. Mock was used as control. This experiment was performed at least 3 times with similar results. (B) Local HR lesions (top) and lesions visualized using trypan blue staining (bottom) on BAT93 leaves inoculated with BPMV-WT at $20^{\circ} \mathrm{C}$. Pictures were taken at $7 \mathrm{dpi}$. (C) Microscopic observations of GFP fluorescence in six inoculated leaves of six different plants of either BAT93 or JaloEEP558, both grown at $20^{\circ} \mathrm{C}$. Observations were made at 4 dpi. The BPMV-GFP construct expressing GFP as an individual protein processed from the RNA2 polyprotein was used as a reporter of BPMV infection. BPMV-WT and Mock were used as control. Yellow triangle indicates GFP foci. Autofluorescence is visible with BPMV-WT and Mock assays. All infection assays were made at $20^{\circ} \mathrm{C}$. Scale bars $=250 \mu \mathrm{m}$. 


\subsection{The R-BPMV Gene Segregates as an Incompletely Dominant Gene}

To determine the inheritance of $R-B P M V$, we investigated the segregation of resistance versus susceptibility to BPMV in an F2 population of 60 plants derived from the cross BAT93 (resistant to BPMV) xJaloEEP558 (susceptible to BPMV). Each F2 plant was inoculated with the construct BPMV-GFP, and resistant/susceptible phenotypes were scored at 7 to $10 \mathrm{dpi}$. The observed segregation ratio was 56 resistant: 4 susceptible. The goodness-of-fit test indicated a significant deviation $\left(\chi^{2}{ }_{1 \mathrm{df}}=10.74, p=0.001\right)$ from the expected Mendelian ratio (3:1) with a deficit of susceptible phenotypes. Thus, the $R-B P M V$ gene segregates as an incompletely dominant gene.

\subsection{At 25 and $30^{\circ} \mathrm{C}, \mathrm{R}-\mathrm{BPMV}$ Induces More Expanded Local HR Lesions}

In previous work, we showed that $R-B P M V$ is closely linked to the $I$ gene at one end of chromosome 2 of $P$. vulgaris [41]. It is known that $I$-mediated resistance is associated with a systemic necrosis that may kill the host when infected by either BCMV above $28^{\circ} \mathrm{C}$ or BCMNV regardless of the temperature [46-48]. Thus, the resistance phenotype conferred by the I gene in response to BCMV infection is temperature-dependent and switches at $28^{\circ} \mathrm{C}$ from extreme resistance to systemic necrosis. In order to check if the resistance mediated by $R-B P M V$ is dependent on temperature, we studied the resistance phenotype at 25 and $30^{\circ} \mathrm{C}$. We first performed inoculation assays using BPMV-WT on the resistant genotype BAT93. We observed that the resistance phenotype is expressed as local HR lesions in the inoculated leaves at all tested temperatures but that HR lesions become more expanded as the temperature increases (Figure 2A). Nevertheless, no vascular systemic necrosis appears at $14 \mathrm{dpi}$ in apical parts of the inoculated plants (Figure 2A). Moreover, no viral symptoms were visible in these apical parts (Figure 2A) and no viral RNAs were detected in systemic leaves of BAT93-inoculated plants at all temperatures (Figure S1). Thus, in our pathosystem, BPMV was blocked in the inoculated leaves and could not spread systemically at all tested temperatures $\left(20,25\right.$, and $\left.30^{\circ} \mathrm{C}\right)$. In conclusion, no switch of phenotype was observed in BAT93 when inoculated with BPMV at either 25 or $30^{\circ} \mathrm{C}$.

In order to assess if larger HR lesions at elevated temperature were correlated with a more expanded multiplication area of BPMV, we scanned the upper surface of the BPMVGFP-inoculated leaves of BAT93 at 4 dpi using an epifluorescence microscope $\left(25^{\circ} \mathrm{C}\right)$ or Axio Zoom microscope $\left(30^{\circ} \mathrm{C}\right)$. JaloEEP558 was used as a susceptible genotype [41]. As expected, at $4 \mathrm{dpi}$, many GFP foci were detected on the upper surface of BPMVGFP inoculated leaves of BAT93 at 25 and $30{ }^{\circ} \mathrm{C}$ (Figure 2B,C). Overall, the GFP foci approximately doubled when shifting from 20 to $25^{\circ} \mathrm{C}$ and from 25 to $30^{\circ} \mathrm{C}$. Thus, BPMV is still able to multiply and to move from cell-to-cell in BAT93 at 25 and $30^{\circ} \mathrm{C}$. Consequently, the plant defense response mediated by $R-B P M V$ seems to become less efficient when temperature increases from 20 to $30^{\circ} \mathrm{C}$ as larger GFP foci are observed. 
A

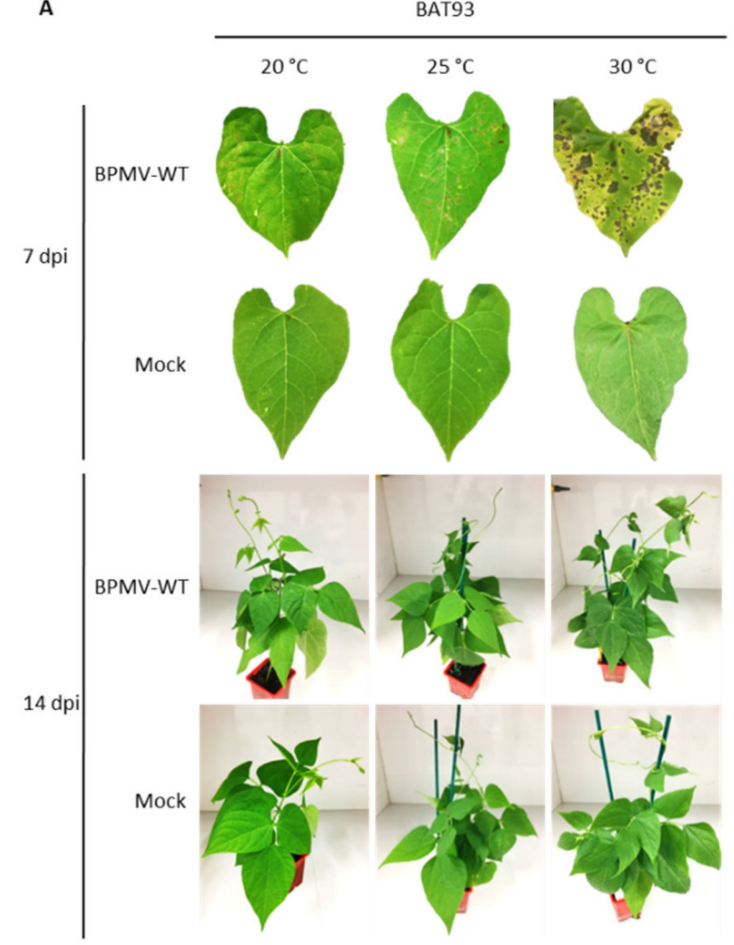

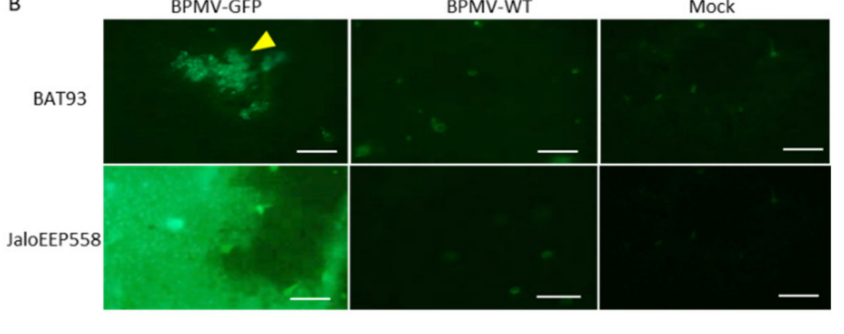

C

GePfluorescence Overlay GFP + chlorophyll

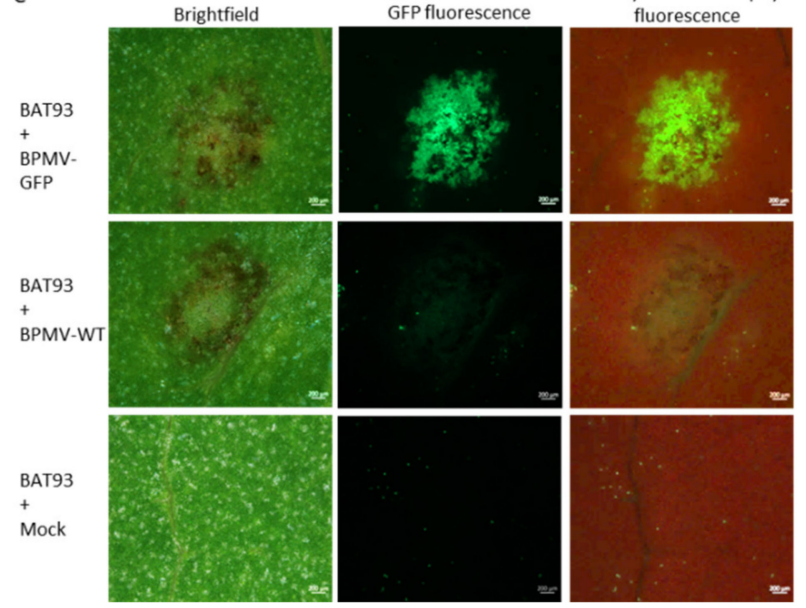

Figure 2. Elevated temperatures promote BPMV multiplication and cell-to-cell movement in the inoculated leaves of cv. BAT93 and larger local Hypersensitive-Response lesions are induced: (A) Representative pictures of local HR lesions on six BAT93-inoculated leaves from six different plants at $20^{\circ} \mathrm{C}, 25^{\circ} \mathrm{C}$ and $30^{\circ} \mathrm{C}$, at 7 days post-inoculation (dpi) with BPMV-WT (upper panel) and six whole plants of BAT93 at $20^{\circ} \mathrm{C}, 25^{\circ} \mathrm{C}$ and $30^{\circ} \mathrm{C}, 14 \mathrm{dpi}$ with BPMV-WT (lower panel). Mock was used as control. This experiment was performed at least 3 times with similar results. (B) Microscopic observations of BPMV-GFP accumulation in inoculated leaves of BAT93 and JaloEEP558 grown at $25^{\circ} \mathrm{C}$. The BPMV-GFP construct expressing GFP as an individual protein processed from the RNA2 polyprotein was used as a reporter of BPMV accumulation. BPMV-WT and Mock were used as control. All infection assays were made at $25^{\circ} \mathrm{C}$. Observations of GFP fluorescence (indicated by a yellow triangle) were made at $4 \mathrm{dpi}$ and are representative of six BAT93-inoculated leaves sampled on six different plants. Scale bars $=250 \mu \mathrm{m}$. (C) Microscopic observations of BPMV-GFP accumulation in inoculated leaves of BAT93 grown at $30^{\circ} \mathrm{C}$. The BPMV-GFP construct expressing GFP as an individual protein processed from the RNA2 polyprotein was used as a reporter of BPMV accumulation. From left to right: brightfield, BPMV-GFP accumulation (green), overlay of chlorophyll fluorescence (red) and BPMV-GFP accumulation (green). BPMV-WT and Mock were used as control. All infection assays were made at $30^{\circ} \mathrm{C}$. Observations of GFP fluorescence were made at $4 \mathrm{dpi}$ and are representative of six BAT93-inoculated leaves sampled on six different plants. Scale bars $=200 \mu \mathrm{m}$.

\subsection{The Resistance Mediated by R-BPMV Is Heat-Stable up to $35^{\circ} \mathrm{C}$ in BAT93, But Local HR Lesions Are Replaced by Chlorotic Lesions}

It is known that some dominant $R$ genes against viruses are overcome at elevated temperatures (e.g., at $28^{\circ} \mathrm{C}$ for $N$ or at $30^{\circ} \mathrm{C}$ for $\left.T s w\right)[22,23,49]$, meaning that the resistance status of the genotype is broken and systemic infection of upper leaves occurs, leading to a susceptible state. We found that $R-B P M V$-mediated resistance was still efficient at temperatures up to $30^{\circ} \mathrm{C}$, but we wanted to test whether higher temperatures $\left(35^{\circ} \mathrm{C}\right)$ could break the resistance conferred by $R-B P M V$. For this purpose, we inoculated BAT93 plants with BPMV-WT and BPMV-GFP and placed the plants at constant $35^{\circ} \mathrm{C}$. As expected, at 7 dpi, HR lesions developed on inoculated leaves of BAT93 + BPMV-WT at $30^{\circ} \mathrm{C}$, and GFP fluorescence was macroscopically detected on inoculated leaves of BAT93 + BPMV-GFP (Figure 3A). By contrast, at $35^{\circ} \mathrm{C}$, only chlorotic lesions (i.e., light-green or yellow local lesions with no visible cell death/necrosis) were visible at $7 \mathrm{dpi}$ on inoculated leaves of BAT93 + BPMV-WT. This appears to correspond to large infection areas, as confirmed 
by expanded GFP foci visible in inoculated leaves of BAT93 + BPMV-GFP (Figure 3A). Quantification of virus titer by RT-PCR in the inoculated leaves of BAT93 confirmed a higher accumulation of viral RNAs at $35^{\circ} \mathrm{C}$ compared to 30 and $20^{\circ} \mathrm{C}$ (Figure $3 \mathrm{~B}, \mathrm{C}$ ).
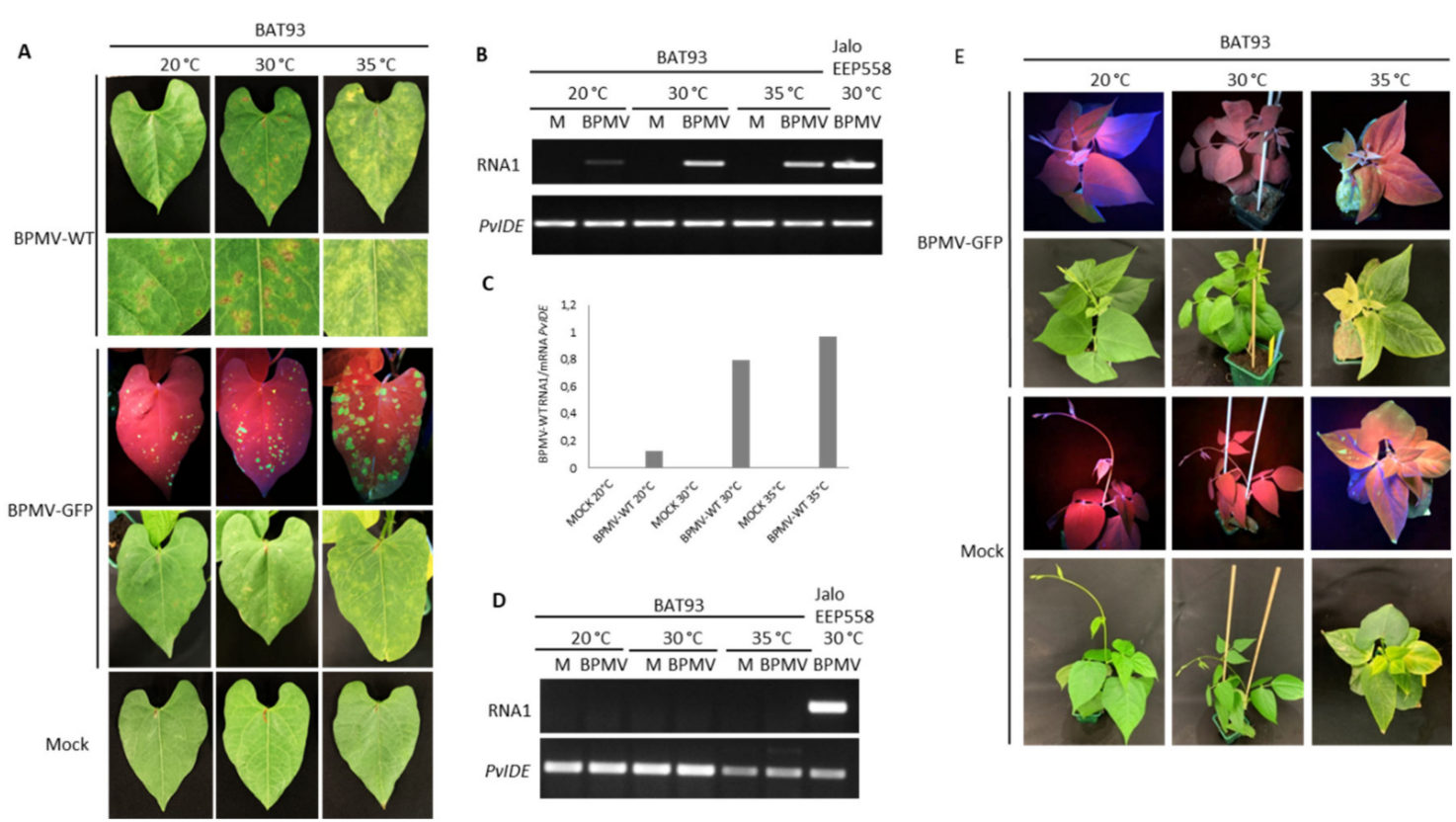

Figure 3. The R-BPMV gene of BAT93 is still efficient to confer BPMV resistance at $35^{\circ} \mathrm{C}$ : (A) Representative pictures of BAT93-inoculated leaves at $20^{\circ} \mathrm{C}, 30^{\circ} \mathrm{C}$ and $35^{\circ} \mathrm{C}, 7$ days post-inoculation (dpi) with BPMV-WT (upper panel; six plants), BPMV-GFP (middle panel; six plants) and Mock (lower panel; six plants). BPMV-GFP was detected under UV light. This experiment was performed at least three times with similar results. (B) Semi-quantitative RT-PCR of BPMV RNA1 (upper panel) in BAT93-inoculated leaves. Plants were inoculated with either mock (M) buffer or BPMV-WT (BPMV) at $20^{\circ} \mathrm{C}, 30^{\circ} \mathrm{C}$ and $35^{\circ} \mathrm{C}$. PvIde was used as an internal control. Total RNA was extracted at 7 dpi from a pool of three BAT93-inoculated leaves sampled on three different plants. A sample of inoculated leaves of JaloEEP558 at $30{ }^{\circ} \mathrm{C}$ was taken as positive control for PCR amplification. (C) Quantification of BPMV titer at 7 dpi in BPMV-WT-inoculated leaves of BAT93 by calculation of the relative ratio of BPMV RNA1 to plant mRNA of PvIde using a quantitative RT-PCR procedure. Data are mean ratios of pools of three BAT93-inoculated leaves sampled on three different plants. (D) Semi-quantitative RT-PCR of BPMV RNA1 (upper panel) in systemic leaves of BAT93 plants inoculated with either mock (M) buffer or BPMV-WT (BPMV) at $20^{\circ} \mathrm{C}, 30^{\circ} \mathrm{C}$ and $35^{\circ} \mathrm{C}$. PvIde was used as an internal control. Total RNA was extracted at 14 dpi from a pool of two systemic leaves (third and fourth trifoliate) sampled on two-three different plants of BAT93. A sample of inoculated leaves of JaloEEP558+BPMV-WT at $30^{\circ} \mathrm{C}$ was taken as positive control for PCR amplification. This experiment was performed twice with similar results. (E) Representative pictures of six whole plants of BAT93 at $20{ }^{\circ} \mathrm{C}, 30{ }^{\circ} \mathrm{C}$ and $35{ }^{\circ} \mathrm{C}, 11 \mathrm{dpi}$ with either BPMV-GFP (upper panel) or mock buffer (lower panel). BPMV-GFP was detected under UV light.

To ensure that no virus moved systemically, we studied the systemic leaves of BAT93 plants grown at $35{ }^{\circ} \mathrm{C}$ and inoculated with either BPMV-WT or BPMV-GFP. No viral RNAs were detected in systemic leaves at $7 \mathrm{dpi}$, and no GFP fluorescence was visible (Figure 3D,E), attesting to the fact that although local infection is of higher intensity, the systemic infection is prevented. Furthermore, no systemic necrosis occurred (Figure 3E). In parallel, we used the susceptible genotype Black Valentine as a control to assess if at $35^{\circ} \mathrm{C}$, BPMV-GFP conserved infectiousness and capacity for systemic movement. We observed that GFP fluorescence was widespread in all systemic leaves of Black Valentine plants at $35^{\circ} \mathrm{C} 7 \mathrm{dpi}$, including stems, while no GFP was detected in the systemic leaves of plants grown at $20^{\circ} \mathrm{C}$ (Figure S2). Overall, our results demonstrate that $R-B P M V$ is heat-stable up to $35^{\circ} \mathrm{C}$. The $R-B P M V$-mediated phenotype is expressed as chlorotic lesions in the inoculated leaves, and no symptoms are detected in the systemic parts. 


\subsection{Elevated Temperatures Boost BPMV Infection in Susceptible Genotypes}

In the resistant genotype BAT93, elevated temperatures (especially $35^{\circ} \mathrm{C}$ ) promoted viral replication and cell-to-cell movement in the inoculated leaves (Figure 3A). Therefore, we investigated the effect of elevated temperatures on BPMV infection in the two susceptible genotypes, JaloEEP558 and Black Valentine. We followed the BPMV-GFP accumulation by visual inspection of plants inoculated with BPMV-GFP grown either at 25 or $30^{\circ} \mathrm{C}$. Compared to control plants at $20^{\circ} \mathrm{C}$, GFP foci at 25 and $30^{\circ} \mathrm{C}$ on inoculated leaves of JaloEEP558 and Black Valentine at $7 \mathrm{dpi}$ were more expanded and confluent on the upper side of the leaves (Figure 4A). Quantification of BPMV RNA1 in leaves inoculated with BPMV-WT confirmed the higher accumulation of BPMV at 25 and $30^{\circ} \mathrm{C}$ compared to $20^{\circ} \mathrm{C}$ (Figure 4B). More precisely, significantly more RNAs were detected at 25 and $30{ }^{\circ} \mathrm{C}$ compared to $20^{\circ} \mathrm{C}$ ( $\sim 6$ fold- and $\sim 7-9$-fold increase, respectively) (Figure 4B). Consequently, BPMV replication and cell-to-cell movement are more efficient from 0 to $7 \mathrm{dpi}$ in the susceptible genotypes JaloEEP558 and Black Valentine at elevated temperature $\left(25\right.$ and $\left.30^{\circ} \mathrm{C}\right)$ compared to $20^{\circ} \mathrm{C}$.

A

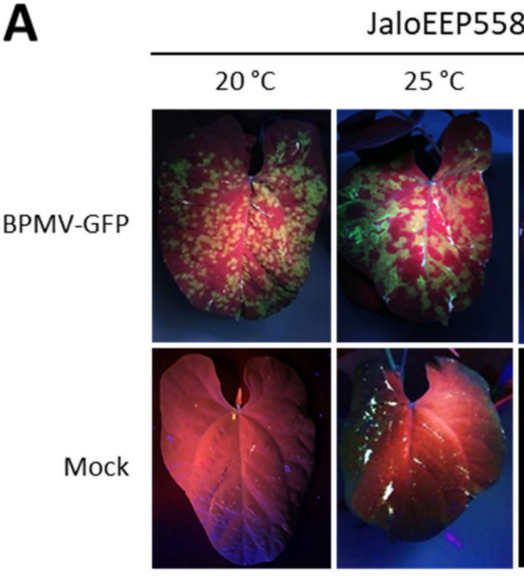

JaloEEP558

B

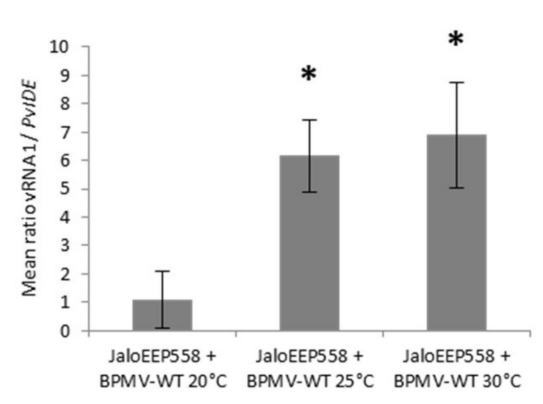

Black Valentine
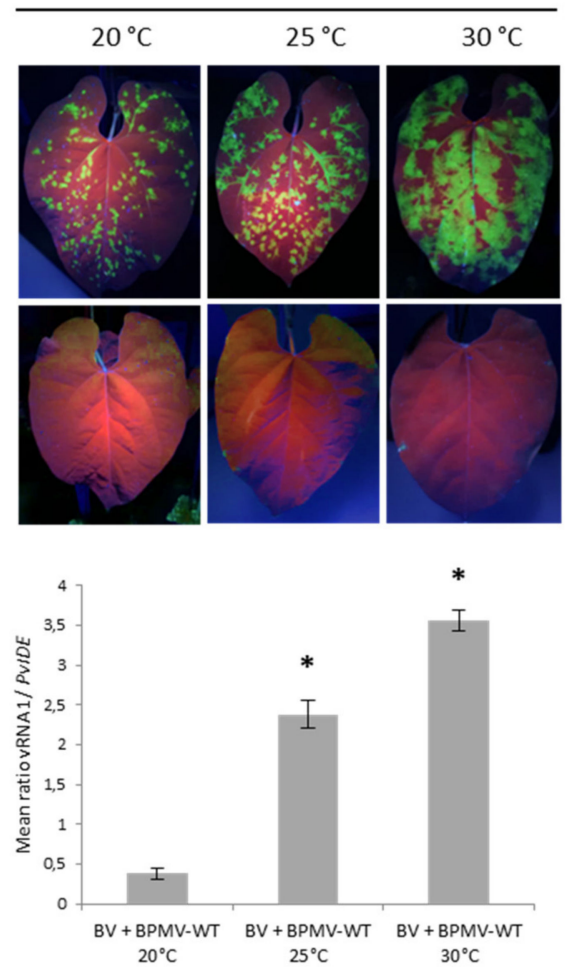

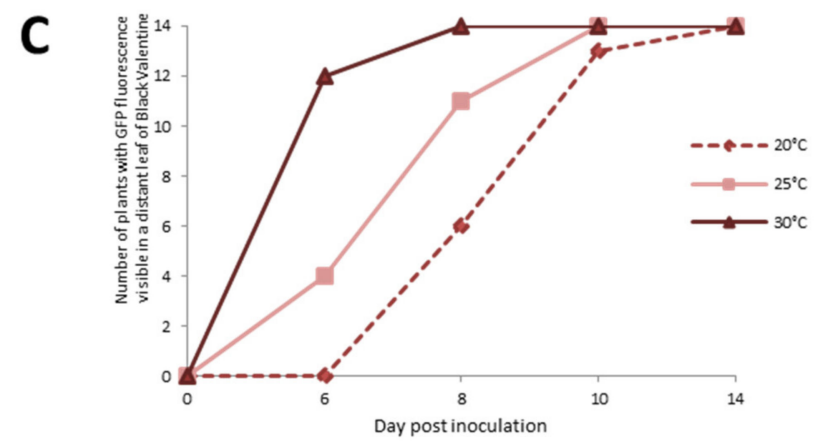

Figure 4. Elevated temperatures promote BPMV infection in the inoculated leaf and BPMV systemic spreading in whole plants of two susceptible genotypes of $P$. vulgaris: (A) Representative pictures of four inoculated leaves from four different plants of either JaloEEP558 or Black Valentine (left and 
right panel, respectively) at $20^{\circ} \mathrm{C}, 25^{\circ} \mathrm{C}$ and $30^{\circ} \mathrm{C}, 7$ days post-inoculation (dpi) with BPMV-GFP (upper panel) and Mock (lower panel). BPMV-GFP was detected under UV light. This experiment was performed at least three times with similar results. (B) Quantification of BPMV titer at $7 \mathrm{dpi}$ in four BPMV-WT-inoculated leaves of four different plants of JaloEEP558 or Black Valentine (BV) by calculation of the relative ratio of BPMV RNA1 to plant mRNA of PvIde using a quantitative RT-PCR procedure. Asteriks indicate significant differences between the tested temperature and $20^{\circ} \mathrm{C}$, the control temperature ( $t$-test, $p$-value $\left.<0,05\right)$. No significant difference of viral titer was found between the two elevated temperatures $25^{\circ} \mathrm{C}$ and $30^{\circ} \mathrm{C}$. Data are mean ratios $\pm \mathrm{SD}$ of four biological replicates. (C) BPMV-GFP systemic spreading in whole plants of Black Valentine at $20^{\circ} \mathrm{C}$, $25{ }^{\circ} \mathrm{C}$, and $30^{\circ} \mathrm{C}$. The graph represents the number of plants with GFP fluorescence visible in a distant leaf scored at four dates after inoculation with BPMV-GFP: 0, 6, 8, 10, and $14 \mathrm{dpi}$ on a total of fourteen plants per temperature assay. BPMV-GFP was detected under UV light. This experiment was performed twice with similar results.

Furthermore, the effect of temperature on the rate of systemic spreading of BPMV-GFP was investigated by scoring the date of appearance of GFP foci on systemic leaves of Black Valentine plants at 20,25, and $30^{\circ} \mathrm{C}$ between 6 and $14 \mathrm{dpi}$. From 6 to $10 \mathrm{dpi}$, the systemic spreading is faster at $30^{\circ} \mathrm{C}$ compared to $25^{\circ} \mathrm{C}$, and at $25^{\circ} \mathrm{C}$ compared to $20^{\circ} \mathrm{C}$ (Figure $4 \mathrm{C}$ ). At $10 \mathrm{dpi}$, GFP foci in systemic leaves of plants at $20^{\circ} \mathrm{C}$ were tiny, whereas GFP fluorescence was widespread at 25 and $30{ }^{\circ} \mathrm{C}$ (Figure S3A). At $14 \mathrm{dpi}$, all plants at 20, 25, and $30{ }^{\circ} \mathrm{C}$ were systemically infected by BPMV-GFP (Figure 4C). High levels of fluorescence were visible in all inoculated parts of plants grown at 25 and $30{ }^{\circ} \mathrm{C}$ (Figure S3B). These results confirm that BPMV systemic movement becomes faster when temperature increases from 20 to $30^{\circ} \mathrm{C}$, resulting in a higher disease incidence in susceptible genotypes.

\subsection{BT-1 and BT-2, Two Near Isogenic Lines for the I. locus, Are Both Resistant to BPMV Systemic Movement}

The $R-B P M V$ gene is closely linked to $I$, a famous locus conferring a broad-spectrum resistance to at least ten different Potyviruses (reviewed in [38]) and several Comoviruses. In this work, we showed that $R-B P M V$ segregates as an incompletely dominant gene. BT-1 (resistant to BCMV, I/I) and BT-2 (susceptible to BCMV, $i / i$ ) are two near-isogenic lines created to study the $I$ locus [42]. We tested them to decipher the resistance mechanism mediated by the R-BPMV gene at the tissue and cell levels, as done for the $I$ locus [50-52]. We challenged BT-1 and BT-2 for their resistance/susceptibility to BPMV at three temperatures: 20, 25, and $30{ }^{\circ} \mathrm{C}$.

At 7 dpi, local HR lesions developed on inoculated leaves of BT-1 and BT-2 at 20 and $25{ }^{\circ} \mathrm{C}$ (Figure 5). As in BAT93, these local HR lesions corresponded to infection areas in which BPMV can first multiply, since small GFP foci were visible after inoculation with BPMV-GFP in BT-1 and BT-2 (Figure 5). Thus, both BT-1 and BT-2 behave as resistant genotypes to BPMV at 20,25 , and $30^{\circ} \mathrm{C}$, and this is strengthened by the observation that no BPMV RNAs were detected in systemic leaves at $21 \mathrm{dpi}$ (Figure S4) as well as no viral symptoms or systemic necrosis (data not shown). In conclusion, BT-1 and BT-2 will not be useful tools to dissect $R-B P M V$-mediated resistance at the cellular level. 


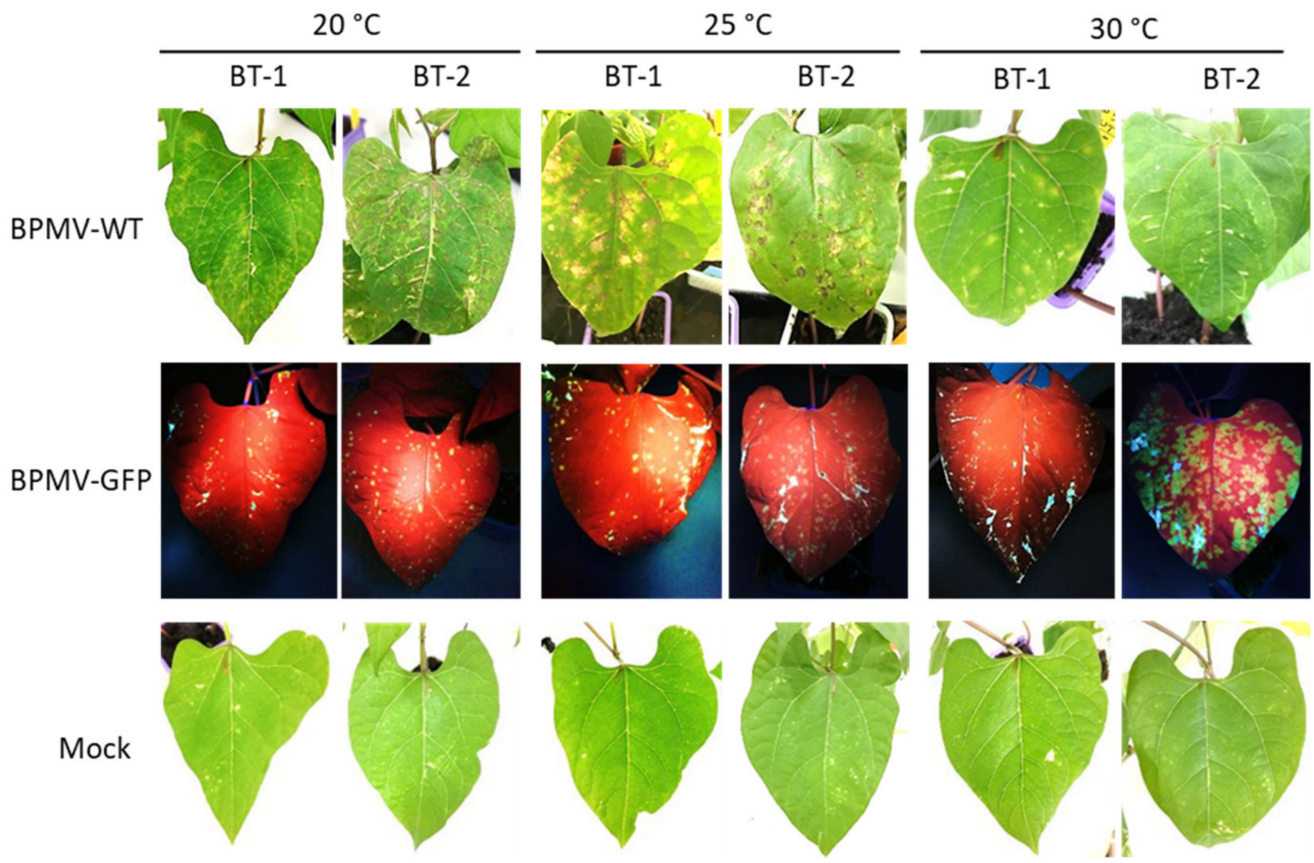

Figure 5. BT-1 and BT-2, two Near Isogenic Lines for the $I$ locus are both resistant to BPMV systemic movement: Representative pictures of four BT-1- and four BT-2-inoculated leaves (sampled on four different plants) grown respectively at $20^{\circ} \mathrm{C}, 30^{\circ} \mathrm{C}$ and $35^{\circ} \mathrm{C}, 7$ days post-inoculation (dpi) with BPMV-WT (upper panel), BPMV-GFP (middle panel), and Mock (lower panel). BPMV-GFP was detected under UV light. This experiment was performed twice with similar results.

\section{Discussion}

In this work, we studied the behavior of the $R-B P M V$-mediated resistance to BPMV in P. vulgaris at normal $\left(20^{\circ} \mathrm{C}\right)$ and elevated temperatures $\left(25,30\right.$, and $\left.35^{\circ} \mathrm{C}\right)$. Strikingly, we found that $R-B P M V$-mediated resistance is heat-stable up to constant $35^{\circ} \mathrm{C}$ at the whole plant level (Figure 3), in the sense that no systemic infection is observed and BPMV remains confined to the inoculated leaf.

This is in agreement with results obtained for other plant-virus pathosystems for which heat-stable $R$ genes have been described. In pepper, different natural allelic variants from the same gene may have different behaviors as reported for the $L^{1 c}$ allele, which is heat-stable at $30^{\circ} \mathrm{C}$, whereas other alleles $\left(L^{1}\right)$ are not [53]. More recently, the potato NLR $R x 1$ gene was reported to confer a temperature-insensitive resistance to PVX in Nicotiana benthamiana that is not overcome at temperatures up to $32^{\circ} \mathrm{C}$, a temperature at which the virus was no longer infectious [24]. Additional heat-stable $R$-gene-mediated resistance has also been reported for pathogens other than viruses. For instance, the tomato Mi-9 gene confers a heat-stable resistance to root-knot nematodes (Meloidogyne sp.) [54,55], despite being homologous to the NLR Mi-1, which is heat-sensitive [56]. In pepper, several heat-stable $R$ genes against Meloidogyne species, named Me, have been reported [57,58]. In Solanum species, $R y_{\text {sto }}$ and $R y_{\text {chc }} R$ genes present in S. stoloniferum and S. chacoense, respectively, confer extreme resistance to the Tobacco veinal necrosis strain of PVY $\left(\mathrm{PVY}^{\mathrm{N}}\right)$ and are functional at both low $\left(16-20^{\circ} \mathrm{C}\right.$ ) and elevated temperatures (above $\left.24{ }^{\circ} \mathrm{C}\right)[59,60]$.

On the other hand, temperature sensitivity has more often been reported in the literature. In tobacco, the NLR $N$ is unable to confer resistance to the Tobacco mosaic virus (TMV) above $28{ }^{\circ} \mathrm{C}[22,49]$. Accordingly, the Capsicum sp. NLR Tsw fails to trigger resistance to the Tomato spotted wilt virus (TSWV) at $32{ }^{\circ} \mathrm{C}$ and above [23,61]. In potato, some $R$ genes conferring HR to PVY including $N y$ in Solanum sparsipilum and S. sucrense, or $\mathrm{Ny}-1$ in $\mathrm{S}$. tuberosum $\mathrm{cv}$. Rywal, confer resistance only at low temperatures $\left(16-20^{\circ} \mathrm{C}\right)$, whereas at higher temperatures $\left(24-28^{\circ} \mathrm{C}\right)$, resistance is inhibited and PVY infects plants systemically [60]. Concerning the other kinds of pathogens, temperature sensitivity has 
been reported for the NLR Mi-1 in tomato (resistance to Meloidogyne incognita, [62]), for the NLR Bs2 in pepper (resistance to Xanthomonas axonopodis pv. vesicatoria, [63]), the non-NLR $C f-4$ and $C f-9$ genes (resistance to Cladosporium fulvum, [64,65]), as well as for many $R$ genes against bacteria in Arabidopsis (e.g., RPS2 and RPM1 resistance to Pseudomonas syringae, [66]; RPS2 and ZAR1 resistance to P. syringae, [67]; RPS4/RRS1-R resistance to Ralstonia solanacearum, [68]; and SNC1 and RPS4 resistance to P. syringae and Peronospora parasitica, [69-71]). All these data converge to assess that temperature sensitivity of resistance is widespread, whereas heat-stable $R$ genes are scarce.

Mechanisms underlying heat sensitivity are poorly understood. Zhu et al. [70] demonstrated that the $\mathrm{R}$ proteins, involved in the recognition of pathogen effectors, can be themselves the causal temperature-sensitive component in defense responses. Indeed, autoimmunity-associated mutations (e.g., mutants in which ETI and spontaneous cell death are constitutively activated) in SNC1, an Arabidopsis NLR-homolog, cause increased SNC1 nuclear localization at $22^{\circ} \mathrm{C}$. In contrast, at $28^{\circ} \mathrm{C}$, the reduced nuclear localization is associated with the suppression of autoimmune phenotypes. Similarly, nuclear localization of the $\mathrm{R}$ protein $\mathrm{N}$ of tobacco was observed after recognition of the TMV coat protein at 22 but not at $28{ }^{\circ} \mathrm{C}$ [70]. When the two SNC1 mutations were introduced into the $N$ gene, resistance was effective at elevated temperature, thus suggesting that these mutations may prevent the temperature-sensitive conformational loss of function of the NLR N [70] and maintaining its interaction with the TMV coat protein [22,49]. It is not excluded that such differential point mutations could exist between $R-B P M V$ and I genes, and one way to confirm this hypothesis would be to clone their corresponding gene sequences. Other putative mechanisms of temperature sensitivity have been proposed such as homeostasis of R-interacting chaperons, reduced $\mathrm{R}$ protein amounts resulting in a lower R activity, and deregulation of nucleo-cytoplasmic localization of $\mathrm{R}$ proteins (reviewed in [18]). More recently, the implication of the methionine cycle [72] and deregulation of the intercellular communication via plasmodesmata [73] have also been supposed to influence virus spread within their hosts.

Our results show that the major gene $R-B P M V$ in $P$. vulgaris genotype BAT93 confers resistance to BPMV by inducing local $\mathrm{HR}$ lesions at $20^{\circ} \mathrm{C}$, where BPMV is able to multiply in a first step (Figure 1). HR lesions have also been observed at 25 and $30^{\circ} \mathrm{C} 7 \mathrm{dpi}$ (Figure 2). Interestingly, at $7 \mathrm{dpi}$, we observed larger $\mathrm{HR}$ lesions at 25 and $30^{\circ} \mathrm{C}$ compared to $20^{\circ} \mathrm{C}$, and this observation was correlated with (i) more expanded multiplication areas of BPMV visualized as green fluorescence areas in BPMV-GFP infected leaves at 4 dpi (Figure 2) and (ii) a rising virus titer in the inoculated leaves at $7 \mathrm{dpi}$ (Figure 3B,C). Consequently, we propose that the higher levels of BPMV accumulation and cell-to-cell spreading in the primary sites of infection could be attributed to a delayed defense response when temperature increases from 20 to $30^{\circ} \mathrm{C}$. As biotrophic pathogens, viruses mainly induce defense responses regulated by salicylic acid (SA) signaling [74], and SA was shown to be a key component that orchestrates the events restricting viral spread in HR [75,76]. Moreover, HR-mediated resistance against Turnip crinkle virus (TCV) was impaired in Arabidopsis eds5 and sid2 SA-deficient mutants without affecting HR cell death [77]. Lukan et al. [78] showed that Potato virus Y (PVY, Potyvirus) spread is even faster in SA-depleted plants (NahGpotato transgenic plants) with rapid lesion expansion. Interestingly, the expression of SA-dependent responses was reduced at elevated temperature in tobacco and potato plants infected with Cucumber mosaic virus (CMV) and PVY, respectively [79,80]. Whether the SA accumulation or other defenses are inhibited or downregulated at elevated temperature needs further work in our pathosystem. Moreover, it has been shown that virus resistance is uncoupled from cell death and that these two events are likely independent [77,78,81-87]. For example, in potato plants bearing the temperature-sensitive $\mathrm{Ny}-1 \mathrm{R}$ gene against PVY, temperature shift assays from 22 to $28{ }^{\circ} \mathrm{C}$ induced the detection of PVY in infected cells outside the cell death zone [78]. Nevertheless, the molecular mechanisms restricting both virus spread and cell death remain unknown [88]. 
Interestingly, at $35{ }^{\circ} \mathrm{C}$, HR lesions that developed on BPMV-inoculated leaves of BAT93 were replaced by chlorotic lesions, while the $R-B P M V$-mediated resistance remains functional at the whole-plant level (Figure 3). We confirmed that BPMV is still infectious and capable of systemic movement at $35^{\circ} \mathrm{C}$ (Figure S2). Thus, it seems that cell death is completely abolished at $35^{\circ} \mathrm{C}$, whereas the local defense response is still efficient to block BPMV systemic infection (Figure 3E). The reduction of cell death at elevated temperature has already been reported in soybean (Glycine max) infected by strains G1 and G7 of Soybean mosaic virus (SMV) [89]. Indeed, a stem-tip necrosis (STN) develops in several soybean cultivars carrying the $R$ genes $R s v 1$ and $R s v 1-n$. The STN in genotype V262 induced by strain G1 and in genotype V94-3971 by strain G7 developed at 10, 15, 20, 25, and $30{ }^{\circ} \mathrm{C}$, on $44,41,14,8$, and 8 days after inoculation, respectively. By contrast, at $35{ }^{\circ} \mathrm{C}$, no STN reaction and, consequently, no cell death was induced by any strain. Interestingly, cell death reduction at elevated temperature has also been reported for plant-bacteria interactions. AvrRpt2-mediated cell death in Dex-AvrRpt2 plants was significantly reduced at $28{ }^{\circ} \mathrm{C}$ and was almost completely abolished at $32{ }^{\circ} \mathrm{C}$ [66]. Interestingly, the expression of the WORKY 46 transcription factor acting as an upstream regulator of SA metabolism was also temperature-sensitive with a peak at $16{ }^{\circ} \mathrm{C}$ and a decrease at temperatures above $28{ }^{\circ} \mathrm{C}$. In the same way, AvrRpm1- and AvrB-mediated cell death was significantly attenuated at elevated temperatures $\left(32^{\circ} \mathrm{C}\right)$ [66]. Thus, the data indicate that elevated temperature could suppress ETI signaling in $R$-gene-mediated response.

We previously showed that $R-B P M V$ is present in genotype BAT93 of $P$. vulgaris and that this gene is genetically linked to the $I$ locus on chromosome 2 [41,90]. The $I$ locus is a broad-spectrum resistance locus that confers resistance to BCMV, BCMNV [91,92], and nine other potyviral species (Watermelon mosaic virus-2 [93,94], Cowpea aphid-borne mosaic virus [93,95], Soybean mosaic virus [96,97], Peanut mottle virus [98,99], Zucchini yellow mosaic virus, Thaïland passiflora mosaic virus, and Passionfruit woodiness virus-K [100], BYMV, and CIYVV [101,102]). Thus, we hypothesized that R-BPMV and I could correspond to the same gene with pleiotropic effects and if so, one important question would be: do $R-B P M V$ and $I$-mediated resistance have the same behavior regarding temperature?

$I$ was reported to be temperature-sensitive for BCMV resistance [47,48]: an extreme resistance or micro-HR phenotypes are observed on inoculated leaves below $28{ }^{\circ} \mathrm{C}$, and BCMV replication was effective [51], but above $28^{\circ} \mathrm{C}$, the ER evolves into a systemic necrosis $[48,50,52]$ (Figure 6). However, for BCMNV, a local HR in inoculated leaves evolves into a systemic necrosis regardless of temperature [46-48] (Figure 6). With BPMV, we observed local HR lesions in inoculated leaves of BAT93 at 20, 25, and $30{ }^{\circ} \mathrm{C}$ at 7 dpi in which BPMV is able to multiply in a first step (Figures 1 and 2). By contrast, at $35^{\circ} \mathrm{C}$, chlorotic lesions develop in inoculated leaves with no BPMV detected in the systemic leaves (Figure 3A), although BPMV is still infectious at $35^{\circ} \mathrm{C}$ in the susceptible genotype BV (Figure S2) with a higher rate of systemic spread at 25,30 , and $35^{\circ} \mathrm{C}$ compared to $20^{\circ} \mathrm{C}$ (Figures S2 and S3). Thus, our results highlight a switch in the resistance phenotype mediated by $R-B P M V$ that occurs between 30 and $35^{\circ} \mathrm{C}$ (Figure 6). Compared to the $I$ gene, this is a significant difference of behavior of the two genetically linked-resistance genes, since $I$ induces local HR and systemic necrosis from $28{ }^{\circ} \mathrm{C}$ with BCMV detected in the inoculated leaves and systemic leaves [50,52] (Figure 6).

Overall, we show here that $R-B P M V$ - and I-mediated resistance phenotypes do not behave in the same way at an elevated temperature. Thus, although genetically tightly linked, BPMV and I could correspond to two different genes. Another hypothesis is that resistance to BPMV and BCMV is controlled by the same gene but that the downstream signaling cascades differ, explaining the two contrasting kinds of resistance phenotypes. Neither I nor R-BPMV has been cloned but both were hypothesized to encode NLR receptors $[90,91,103]$. Consistent with this hypothesis, the resistance phenotypes are expressed for $I$ as either extreme resistance or systemic necrosis or for $R-B P M V$ as local HR, which are hallmarks of ETI mediated by NLR receptors. Moreover, Vallejos et al. [91] reported an 
over-expression of several NLR genes of the I region after BCMV or BCMNV inoculations, suggesting a role of NLR genes in the response to BCMV/BCMNV.

A

Virus Genotype

Temperature

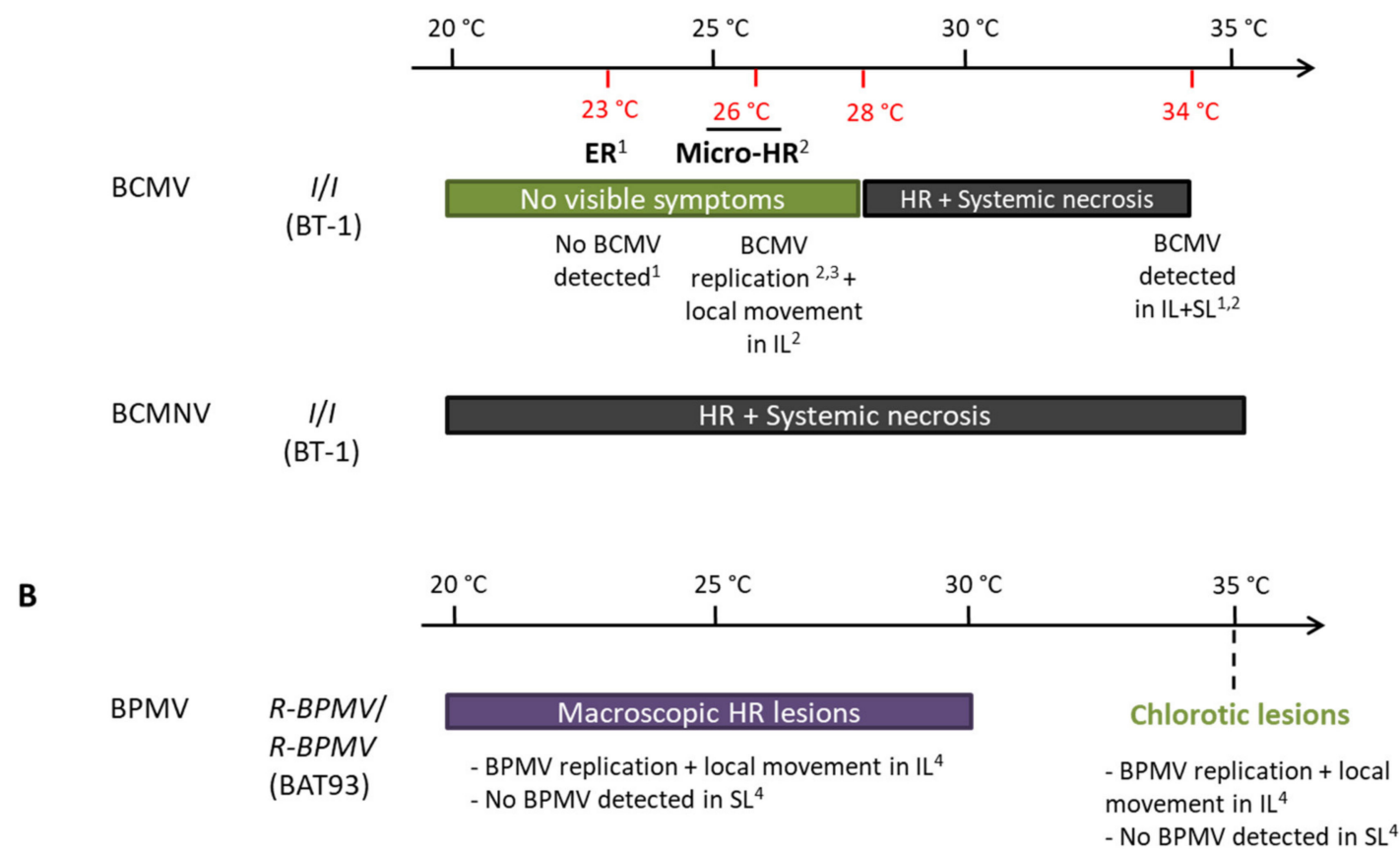

Figure 6. Resistance phenotypes of $R-B P M V$ - and I-derived resistances do not share the same features regarding temperature: (A)Potyviruses Bean common mosaic virus (BCMV) and Bean common mosaic necrosis virus (BCMNV); (B)Comovirus Bean pod mottle virus (BPMV) Abreviations: ER: Extreme resistance, HR: Hypersensitive Reaction, IL: inoculated leaf, MicroHR: microscopic Hypersensitive Reaction, SL: systemic leaf. References: 1: Collmer et al. 2000 (whole-plant study); 2: Cadle-Davidson and Jahn 2006 (whole-plant study); 3: Cadle-Davidson and Jahn 2005 (BCMV transfection in protoplasts); 4: this study.

Finally, it is worth noting that both $R-B P M V$ (our study) and I segregate as incompletely dominant genes $[50,51,91]$. Indeed, when investigating the inheritance of $R$-BPMV in an F2 population of 60 plants, we found a deficit of susceptible phenotypes (56 resistant: 4 susceptible) and thus, a significant deviation from the expected Mendelian ratio (3:1). A similar segregation deviation was reported for the I gene in an F2 population obtained from the cross Calima (susceptible Andean genotype) $\times$ Jamapa (resistant Mesoamerican genotype) [91]. Vallejos et al. [91] suggested that this phenomenon was a consequence of the partial compatibility of the Andean and Mesoamerican genomes interacting in this type of crosses [91].

To study the effect of elevated temperatures in a P. vulgaris-BPMV compatible interaction, we performed experiments on two BPMV-susceptible genotypes P. vulgaris cv. Black Valentine and cv. JaloEEP558. We reported that in both genotypes, the area of primary infection sites at $7 \mathrm{dpi}$ was larger on BPMV-GFP-inoculated leaves at 25 and $30^{\circ} \mathrm{C}$ compared to $20^{\circ} \mathrm{C}$, and these results were correlated with a higher virus titer in these leaves (Figure 4A,B). Moreover, in Black Valentine, the virus spreads systemically even more rapidly when the temperature increases (Figure 4 C). Overall, our results show a positive effect of temperature elevation on the level of susceptibility in two susceptible genotypes. Our results are in agreement with several other studies on different plant-virus interactions in compatible contexts. For example, Chung et al. [29] investigated the effects of different temperature regimes on the speed of systemic spread after inoculation of Turnip mosaic virus (TuMV) in Chinese cabbage. It took 48 days for systemic infection to occur at $13{ }^{\circ} \mathrm{C}$ but only 6 days at $22-33^{\circ} \mathrm{C}$. Likewise, in Solanum tuberosum, plants became 
$100 \%$ systemically infected at 24 and $28{ }^{\circ} \mathrm{C}$, while at $20^{\circ} \mathrm{C}$, only $20 \%$ of the plants were systemically infected [26,27]. Nancarrow et al. [27] studied the effects of elevated $\left(10-21^{\circ} \mathrm{C}\right.$, night/ day) or ambient $\left(5-16^{\circ} \mathrm{C}\right.$, night/day) temperature winter growing season regimes on wheat plants infected with Barley yellow dwarf virus (BYDV, Luteovirus). Infected plants grown under an elevated temperature developed virus symptoms earlier and had higher virus titers than plants grown at an ambient temperature. In potato, susceptibility to PVY was dramatically increased in systemic infected leaves at higher temperatures [80]. In cassava, geminiviruses responsible for cassava mosaic disease cause more symptoms and have higher viral titer at $25{ }^{\circ} \mathrm{C}$ compared to $30{ }^{\circ} \mathrm{C}$ [32]. Nevertheless, other studies have shown opposite results, showing a negative effect on the level of susceptibility in susceptible genotypes. In $N$. benthamiana, plants infected with the potyviruses PVY and Potato virus $A$ had fewer symptoms and reduced $\mathrm{CP}$ protein accumulation at $20^{\circ} \mathrm{C}$ compared to $30{ }^{\circ} \mathrm{C}$ [104]. In the same way, Del Toro et al. [30] worked in N. benthamiana infected with PVY and PVX and showed attenuated symptoms for PVY and no symptoms for PVX at $30{ }^{\circ} \mathrm{C}$ compared to $25^{\circ} \mathrm{C}$. Aguilar et al. [105] described that elevated temperatures decrease both virulence and virus titers in the synergistic infection PVX/Plum pox virus (PPV) in $N$. benthamiana. Importantly, the RNA silencing machinery was shown to be more active at elevated temperatures in several plants including cassava and N. benthamiana [32,106], suggesting that more efficient RNA silencing is responsible for impaired viral replication (or the viral RNA suppressor is less active). To conclude, all these studies demonstrate that depending on the virus and plant host, elevated temperature may either increase or decrease virus susceptibility. To investigate this differential impact, further studies are needed on other pathosystems in the future. Moreover, molecular mechanisms underlying the differential susceptibility to viruses must be investigated in more depth, especially concerning the implication of the RNA silencing pathway in pathosystems for which viral infection is boosted at elevated temperature such as P. vulgaris-BPMV.

Global warming leads to rising temperatures, which alter plant-virus interactions [73], potentially inducing yield losses and decreasing quality of crop productions [107]. It is therefore timely to study the effect of elevated temperatures on plant responses to virus infections. Importantly, future experiments on the effect of temperature on plant-virus interactions will need to consider the dynamic nature of field conditions, with diurnal fluctuating temperature cycles and heat waves such as those experienced by crops in the field. As performed in Nancarrow et al. [27], growing chambers will need to more closely resemble the dynamic conditions to which plants and pathogens are subjected in nature so that field trials can be mimicked. After studying the effect of a single environmental factor in order to have a specific response, it will be important to test the effect of several combined environmental factors (elevated temperature + high $\mathrm{CO}_{2}$ for example) to analyze whether their effects are additive or antagonistic. In C3 plants like P. vulgaris, high $\mathrm{CO}_{2}$ improves photosynthesis and activates hormonal pathways, whereas high temperatures decrease the efficiency of Rubisco and the solubility of $\mathrm{CO}_{2}$. Consequently, combined high $\mathrm{CO}_{2}$ and elevated temperatures may induce antagonistic effects. At the international level, little work has been published on the combined effects of elevated temperatures and high $\mathrm{CO}_{2}$ on plant-virus interactions (reviewed in [20]). Del Toro et al. [108] focused on combined climate conditions (CCC, elevated temperature (30 versus $25^{\circ} \mathrm{C}$ ) and high $\mathrm{CO}_{2}$ level (970 versus 405 ppm)) by studying CMV, PVY, and PVX in the model plant $N$. benthamiana. They showed that viral titers in systemic leaves under CCC showed no significant differences at 7 and $12 \mathrm{dpi}$ for CMV. Conversely, viral titers of PVY and PVX were significantly lower under CCC compared to the standard condition at both 7 and 12 dpi. In the case of PVY, viral titer was lower at 12 dpi compared to 7 dpi under CCC, and the contrary was observed for PVX [108]. In potato (S. tuberosum), Chung et al. [109] demonstrated that Potato leaf roll virus (PLRV) RNA accumulated at higher levels, and larger numbers of potato plants were infected by PLRV under combined high $\mathrm{CO}_{2}$ levels $(940 \mathrm{ppm})$ and elevated temperature $\left(30^{\circ} \mathrm{C}\right)$. More recently, Aguilar et al. [110] studied a multifactorial system combining biotic (virus and bacteria) and abiotic (drought) stresses 
in A. thaliana (compatible context) and N. benthamiana plants (incompatible context). They demonstrated that infection by the PVX/PPV virus combination induced resistance to the bacteria P. syringae pv. tomato and to drought in both compatible and incompatible host-bacteria interactions. However, combined high $\mathrm{CO}_{2}$ levels (970 ppm) and elevated temperature $\left(30^{\circ} \mathrm{C}\right)$ negatively affected resistance to $P_{s t}$ and to drought induced by a virus infection, and this correlated with diminished $\mathrm{H}_{2} \mathrm{O}_{2}$ production, decreased expression of defense genes, and a drop in virus titers.

\section{Conclusions}

To conclude, our study gives a first insight into the impact of elevated temperature on the level of resistance/susceptibility to viruses in common bean. Indeed, natural genetic resistance is often the most effective and environmentally friendly way of controlling plant diseases, in particular against a virus where no chemical alternative is available. This research needs to be continued in order to decipher the underlying cellular and molecular mechanisms of heat tolerance and to engineer robust thermostable resistances in the context of global warming.

Supplementary Materials: The following are available online at https:/ /www.mdpi.com/article/10 $.3390 / \mathrm{v} 13071239 / \mathrm{s} 1$, Figure S1, Semi-quantitative RT-PCR showing that $P$. vulgaris cv. BAT93 is resistant to BPMV systemic infection; Figure S2, BPMV is still infectious at $35^{\circ} \mathrm{C}$ and spreads systemically in the susceptible genotype P. vulgaris cv. Black Valentine; Figure S3, Elevated temperatures promote BPMV spreading in the systemic leaves and in whole plants in the susceptible genotype $P$. vulgaris $\mathrm{cv}$. Black Valentine; Figure S4, Semi-quantitative RT-PCR showing that P. vulgaris cv. BT-1 and BT-2, two Near Isogenic Lines for the I locus, are both resistant to BPMV systemic infection.

Author Contributions: Conceptualization, C.M. and S.P.; methodology, C.M. and S.P.; formal analysis, C.M., J.L., A.G.-W. and S.P.; investigation, C.M., J.L., C.G., M.N., S.B., A.N. and S.P.; writing, C.M., J.L., S.B., M.N. and S.P.; manuscript editing, C.M., J.L., M.N., S.B., A.G.-W., V.G. and S.P.; supervision and project administration, S.P.; funding acquisition, V.G. and S.P. All authors have read and agreed to the published version of the manuscript.

Funding: C.M. and J.L. were supported by fellowships from the French Research Ministry and from the « Ecole Universitaire de Recherche Saclay Plant Sciences (EUR SPS) Graduate School of Research », respectively. MN was supported by an individual 'Invited-researcher' fellowship from Université de Paris in 2019 and 2021. This work was supported by fundings from the Plant Biology and Breeding (BAP) department of French National Research Institute for Agriculture, Food, and Environment (INRAE) (HiT-VIRUSRESIST project), from the French National Research Agency (HiPATH project, Grant Agreement No. ANR-17-CE20-0025), and from the European Union's Horizon 2020 research and innovation program (BRESOV project, Grant Agreement No. 774244). IPS2 benefits from the support of Saclay Plant Sciences-SPS (ANR-17-EUR-0007).

Institutional Review Board Statement: Not applicable.

Informed Consent Statement: Not applicable.

Data Availability Statement: Data sharing is not applicable to this article.

Acknowledgments: We thank Séverine Domenichini and Gautier Bernal from IPS2 for their implication in the microscope work. We also thank Chunquan Zhang and Steven Whitham at Iowa State University, USA, for sharing the set of BPMV vectors and for providing the seeds of $P$. vulgaris cv. Black Valentine, Juan Camilo Alvarez Diaz and Etienne Delannoy for advices with RT-qPCR analysis and quantification of BPMV virus titer, Manon Richard for managing the construction of the F2 population, Holger Ornstrup and all the greenhouse team of IPS2 for precious help with plant growing, and Benoît Moury and Cécile Desbiez of INRAE Avignon, France, for helpful discussions.

Conflicts of Interest: The authors declare no conflict of interest.

\section{Abreviations}




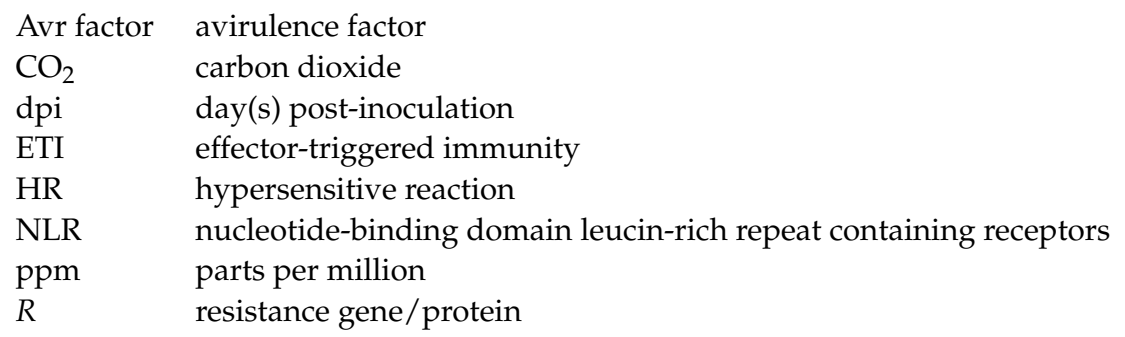

\section{References}

1. Anderson, P.K.; Cunningham, A.A.; Patel, N.G.; Morales, F.J.; Epstein, P.R.; Daszak, P. Emerging infectious diseases of plants: Pathogen pollution, climate change and agrotechnology drivers. Trends Ecol. Evol. 2004, 19, 535-544. [CrossRef]

2. Sastry, K.S.; Zitter, T.A. Plant Virus and Viroid Diseases in the Tropics. Volume 2: Epidemiology and Management; Springer: Dordrecht, The Netherlands, 2014.

3. Amari, K.; Niehl, A. Nucleic acid-mediated PAMP-triggered immunity in plants. Curr. Opin. Virol. 2020, 42, 32-39. [CrossRef]

4. Ratcliff, F.; Harrison, B.D.; Baulcombe, D.C. A similarity between viral defense and gene silencing in plants. Science 1997, 276, 1558-1560. [CrossRef] [PubMed]

5. Kørner, C.; Klauser, D.; Niehl, A.; Domínguez-Ferreras, A.; Chinchilla, D.; Boller, T.; Heinlein, M.; Hann, D.R. The immunity regulator BAK1 contributes to resistance against diverse RNA viruses. Mol. Plant Microbe Interact. 2013, 26, 1271-1280. [CrossRef]

6. Lee, B.; Park, Y.S.; Lee, S.; Song, G.C.; Ryu, C.M. Bacterial RNAs activate innate immunity in Arabidopsis. New Phytol. 2016, 209, 785-797. [CrossRef]

7. Niehl, A.; Wyrsch, I.; Boller, T.; Heinlein, M. Double-stranded RNAs induce a pattern-triggered immune signaling pathway in plants. New Phytol. 2016, 1-12. [CrossRef] [PubMed]

8. Csorba, T.; Kontra, L.; Burgyán, J. Viral silencing suppressors: Tools forged to fine-tune host-pathogen coexistence. Virology 2015, 479-480, 85-103. [CrossRef] [PubMed]

9. Zvereva, A.S.; Golyaev, V.; Turco, S.; Gubaeva, E.G.; Rajeswaran, R.; Schepetilnikov, M.V.; Srour, O.; Ryabova, L.A.; Boller, T.; Pooggin, M.M. Viral protein suppresses oxidative burst and salicylic acid-dependent autophagy and facilitates bacterial growth on virus-infected plants. New Phytol. 2016, 211, 1020-1034. [CrossRef]

10. Nicaise, V.; Candresse, T. Plum pox virus capsid protein suppresses plant pathogen-associated molecular pattern (PAMP)triggered immunity. Mol. Plant Pathol. 2017, 18, 878-886. [CrossRef] [PubMed]

11. Kong, J.; Wei, M.; Li, G.; Lei, R.; Qiu, Y.; Wang, C.; Li, Z.H.; Zhu, S. The cucumber mosaic virus movement protein suppresses PAMP-triggered immune responses in Arabidopsis and tobacco. Biochem. Biophys. Res. Commun. 2018, 498, 395-401. [CrossRef]

12. Palukaitis, P.; Yoon, J.Y. R gene mediated defense against viruses. Curr. Opin. Virol. 2020, 45, 1-7. [CrossRef]

13. Flor, H.H. Current status of the gene-for-gene concept. Annu. Rev. Phytopathol. 1955, 1971, 275-296. [CrossRef]

14. Gouveia, B.C.; Calil, I.P.; Machado, J.P.B.; Santos, A.A.; Fontes, E.P.B. Immune Receptors and Co-receptors in Antiviral Innate Immunity in Plants. Front. Microbiol. 2017, 7, 2139. [CrossRef] [PubMed]

15. De Ronde, D.; Butterbach, P.; Kormelink, R. Dominant resistance against plant viruses. Front. Plant Sci. 2014, 5, 307. [CrossRef]

16. Kou, Y.; Wang, S. Broad-spectrum and durability: Understanding of quantitative disease resistance. Curr. Opin. Plant Biol. 2010, 13, 181-185. [CrossRef]

17. Schmitt-Keichinger, C. Manipulating cellular factors to combat viruses: A case study from the plant eukaryotic translation initiation factors eIF4. Front. Microbiol. 2019, 10, 1-8. [CrossRef] [PubMed]

18. Venkatesh, J.; Kang, B.C. Current views on temperature-modulated R gene-mediated plant defense responses and tradeoffs between plant growth and immunity. Curr. Opin. Plant Biol. 2019, 50, 9-17. [CrossRef] [PubMed]

19. Trebicki, P. Climate change and plant virus epidemiology. Virus Res. 2020, 286, 198059. [CrossRef]

20. Tenllado, F.; Canto, T. Effects of a changing environment on the defenses of plants to viruses. Curr. Opin. Virol. 2020, 42, 40-46. [CrossRef]

21. Desaint, H.; Aoun, N.; Deslandes, L.; Vailleau, F.; Roux, F.; Berthomé, R. Fight hard or die trying: When plants face pathogens under heat stress. New Phytol. 2021, 229, 712-734. [CrossRef] [PubMed]

22. Weststeijn, E. Lesion growth and virus localization in leaves of Nicotiana tabacum cv. Xanthi nc. after inoculation with tobacco mosaic virus and incubation alternately at $22^{\circ} \mathrm{C}$ and $32{ }^{\circ} \mathrm{C}$. Physiol. Plant Pathol. 1981, 18, 357-368. [CrossRef]

23. Chung, B.N.; Lee, J.H.; Kang, B.C.; Koh, S.W.; Joa, J.H.; Choi, K.S.; Ahn, J.J. HR-mediated defense response is overcome at high temperatures in capsicum species. Plant Pathol. J. 2018, 34, 71-77. [CrossRef] [PubMed]

24. Richard, M.M.S.; Knip, M.; Aalders, T.; Beijaert, M.S.; Takken, F.L.W. Unlike Many Disease Resistances, Rx1-Mediated Immunity to Potato Virus X Is Not Compromised at Elevated Temperatures. Front. Genet. 2020, 11, 1-8. [CrossRef]

25. Kabbage, M.; Kessens, R.; Bartholomay, L.C.; Williams, B. The Life and Death of a Plant Cell. Annu. Rev. Plant Biol. 2017, 68, 375-404. [CrossRef] [PubMed]

26. Choi, K.S.; del Toro, F.; Tenllado, F.; Canto, T.; Chung, B.N. A model to explain temperature dependent systemic infection of potato plants by Potato virus Y. Plant Pathol. J. 2017, 33, 206-211. [CrossRef] 
27. Nancarrow, N.; Constable, F.E.; Finlay, K.J.; Freeman, A.J.; Rodoni, B.C.; Trebicki, P.; Vassiliadis, S.; Yen, A.L.; Luck, J.E. The effect of elevated temperature on barley yellow dwarf virus-PAV in wheat. Virus Res. 2014, 186, 97-103. [CrossRef]

28. Kido, K.; Tanaka, C.; Mochizuki, T.; Kubota, K.; Ohki, T.; Ohnishi, J.; Knight, L.M.; Tsuda, S. High temperatures activate local viral multiplication and cell-to-cell movement of Melon necrotic spot virus but restrict expression of systemic symptoms. Phytopathology 2008, 98, 181-186. [CrossRef] [PubMed]

29. Chung, B.N.; Choi, K.S.; Ahn, J.J.; Joa, J.H.; Do, K.S.; Park, K.S. Effects of temperature on systemic infection and symptom expression of turnip mosaic virus in Chinese cabbage (Brassica campestris). Plant Pathol. J. 2015, 31, 363-370. [CrossRef]

30. Del Toro, F.J.; Aguilar, E.; Hernández-Walias, F.J.; Tenllado, F.; Chung, B.N.; Canto, T. High temperature, high ambient CO2 affect the interactions between three positive-sense RNA viruses and a compatible host differentially, but not their silencing suppression efficiencies. PLoS ONE 2015, 10, 1-18. [CrossRef]

31. Dahal, G.; Hughes, J.D.; Thottappilly, G.; Lockhart, B.E.L. Effect of temperature on symptom expression and reliability of banana streak badnavirus detection in naturally infected plantain and banana (Musa spp.). Plant Dis. 1998, 82, 16-21. [CrossRef] [PubMed]

32. Chellappan, P.; Vanitharani, R.; Ogbe, F.; Fauquet, C.M. Effect of temperature on geminivirus-induced RNA silencing in plants. Plant Physiol. 2005, 138, 1828-1841. [CrossRef] [PubMed]

33. Broughton, W.J.; Hernandez, G.; Blair, M.; Beebe, S.; Gepts, P.; Vanderleyden, J. Beans (Phaseolus spp.)—Model food legumes. Plant Soil 2003, 252, 55-128. [CrossRef]

34. Beebe, S.; Ramirez, J.; Jarvis, A.; Rao, I.M.; Mosquera, G.; Bueno, J.M.; Blair, M.W. Genetic Improvement of Common Beans and the Challenges of Climate Change. Crop Adapt. Clim. Chang. 2011, 356-369. [CrossRef]

35. Julian R-Climate Change and Bean Production. Available online: https://pt.slideshare.net/ciatdapa/julian-r-climate-changeand-bean-production/2 (accessed on 25 April 2021).

36. Omae, H.; Kumar, A.; Kashiwaba, K.; Shono, M. Adaptation to high temperature and water deficit in the common bean (Phaseolus vulgaris L.) during the reproductive period. J. Bot. 2012. [CrossRef]

37. Suarez, J.C.; Polania, J.A.; Contreras, A.T.; Rodriguez, L.; Machado, L.; Ordonez, C.; Beebe, S.; Rao, I. Adaptation of common bean lines to high temperature conditions: Genotypic differences in phenological and agronomic performance Adaptation of common bean lines to high temperature conditions: Genotypic differences in phenological and agronomic performan. Euphytica 2020, 216, 28. [CrossRef]

38. Meziadi, C.; Blanchet, S.; Geffroy, V.; Pflieger, S. Genetic resistance against viruses in Phaseolus vulgaris L.: State of the art and future prospects. Plant Sci. 2017, 265, 39-50. [CrossRef] [PubMed]

39. Morales, F.J.; Castano, M. Increased disease severity induced by some comoviruses in bean genotypes possessing monogenic dominant resistance to Bean common mosaic potyvirus. Plant Dis. 1992, 76, 570-573. [CrossRef]

40. Morales, F.J.; Singh, S.P. Inheritance of the mosaic and necroses reactions induced by bean severe mosaic comoviruses in Phaseolus vulgaris L. Euphytica 1997, 93, 223-226. [CrossRef]

41. Pflieger, S.; Blanchet, S.; Meziadi, C.; Richard, M.M.S.; Thareau, V.; Mary, F.; Mazoyer, C.; Geffroy, V. The “ one-step " Bean pod mottle virus (BPMV)—Derived vector is a functional genomics tool for efficient overexpression of heterologous protein, virus-induced gene silencing and genetic mapping of BPMV R-gene in common bean (Phaseolus vulgaris L.). BMC Plant Biol. 2014, 14, 1-16. [CrossRef] [PubMed]

42. Provvidenti, R. Two useful selections of the bean cultivar Black Turtle Soup for viral identification. Bean Improv. Coop. Annu. Rep. 1983, 26, 73-75.

43. Zhang, C.; Bradshaw, J.D.; Whitham, S.A.; Hill, J.H. The Development of an Efficient Multipurpose Bean Pod Mottle Virus Viral Vector Set for Foreign Gene Expression and RNA silencing. Plant Physiol. 2010, 153, 52-65. [CrossRef] [PubMed]

44. Pflieger, S.; Blanchet, S.; Meziadi, C.; Richard, M.M.S.; Geffroy, V. Bean pod mottle virus (BPMV) viral inoculation procedure in common bean (Phaseolus vulgaris L.). Bio-Protocol 2015, 5, e1524. [CrossRef]

45. Richard, M.M.S.; Gratias, A.; Alvarez Diaz, J.C.; Thareau, V.; Pflieger, S.; Meziadi, C.; Blanchet, S.; Marande, W.; Bitocchi, E.; Papa, R.; et al. A common bean truncated CRINKLY4 kinase controls gene-for-gene resistance to the fungus Colletotrichum lindemuthianum. J. Exp. Bot. 2021, 72, 3569-3581. [CrossRef]

46. Ali, M.A. Genetics of resistance to the common Bean mosaic virus in the bean (Phaseolus vulgaris L). Phytopathology 1950, 40, 69-79.

47. Bos, L. Bean common mosaic virus. C. Descr. Plant Viruses 1971, 73.

48. Drijfhout, E. Genetic Interaction between Phaseolus vulgaris and bean Common Mosaic Virus with Implications for Strain Identification and Breeding for Resistance; Centre for Agricultural Publishing and Documentation: Wageningen, The Netherlands, 1978.

49. Whitham, S.; McCormick, S.; Baker, B. The N gene of tobacco confers resistance to tobacco mosaic virus in transgenic tomato. Proc. Natl. Acad. Sci. USA 1996, 93, 8776-8781. [CrossRef] [PubMed]

50. Collmer, C.W.; Marston, M.F.; Taylor, J.C.; Jahn, M. The I gene of bean: A dosage-dependent allele conferring extreme resistance, hypersensitive resistance, or spreading vascular necrosis in response to the potyvirus Bean common mosaic virus. Mol. Plant Microbe Interact. 2000, 13, 1266-1270. [CrossRef]

51. Cadle-Davidson, M.M.; Jahn, M.M. Resistance conferred against bean common mosaic virus by the incompletely dominant I locus of Phaseolus vulgaris is active at the single cell level. Arch. Virol. 2005, 150, 2601-2608. [CrossRef]

52. Cadle-Davidson, M.M.; Jahn, M.M. Patterns of accumulation of Bean common mosaic virus in Phaseolus vulgaris genotypes nearly isogenic for the I locus. Ann. Appl. Biol. 2006, 148, 179-185. [CrossRef] 
53. Tomita, R.; Sekine, K.-T.; Mizumoto, H.; Sakamoto, M.; Murai, J.; Kiba, A.; Hikichi, Y.; Suzuki, K.; Kobayashi, K. Genetic Basis for the Hierarchical Interaction between Tobamovirus spp. and L Resistance Gene Alleles from Different Pepper Species. Mol. Plant Microbe Interact. 2011, 24, 108-117. [CrossRef]

54. Veremis, J.C.; van Heusden, A.W.; Roberts, P.A. Mapping a novel heat-stable resistance to Meloidogyne in Lycopersicon peruvianum. Theor. Appl. Genet. 1999, 98, 274-280. [CrossRef]

55. Ammiraju, J.S.S.; Veremis, J.C.; Huang, X.; Roberts, P.A.; Kaloshian, I. The heat-stable root-knot nematode resistance gene Mi-9 from Lycopersicon peruvianum is localized on the short arm of chromosome 6. Theor. Appl. Genet. 2003, 106, 478-484. [CrossRef]

56. Jablonska, B.; Ammiraju, J.S.S.; Bhattarai, K.K.; Mantelin, S.; de Ilarduya, O.M.; Roberts, P.A.; Kaloshian, I. The Mi-9 gene from Solanum arcanum conferring heat-stable resistance to root-knot nematodes is a homolog of Mi-1. Plant Physiol. 2007, 143, 1044-1054. [CrossRef]

57. Djian-Caporalino, C.; Pijarowski, L.; Januel, A.; Lefebvre, V.; Daubèze, A.; Palloix, A.; Dalmasso, A.; Abad, P. Spectrum of resistance to root-knot nematodes and inheritance of heat-stable resistance in in pepper (Capsicum annuum L.). Theor. Appl. Genet. 1999, 99, 496-502. [CrossRef] [PubMed]

58. Djian-Caporalino, C.; Pijarowski, L.; Fazari, A.; Samson, M.; Gaveau, L.; O’Byrne, C.; Lefebvre, V.; Caranta, C.; Palloix, A.; Abad, P. High-resolution genetic mapping of the pepper (Capsicum annuum L.) resistance loci Me3 and Me4 conferring heat-stable resistance to root-knot nematodes (Meloidogyne spp.). Theor. Appl. Genet. 2001, 103, 592-600. [CrossRef]

59. Bradshaw, J.; Ramsey, G. Utilisation of the Commonwealth Potato Collection in potato breeding. Euphytica 2005, 146, 919. [CrossRef]

60. Solomon-Blackburn, R.; Bradshaw, J. Resistance to Potato virus Y in a Multitrait Potato Breeding Scheme without Direct Selection in Each Generation. Potato Res. 2007, 50, 87-95. [CrossRef]

61. Moury, B.; Selassie, K.G.; Marchoux, G.; Daub, A.; Palloix, A. High temperature effects on hypersensitive resistance to Tomato Spotted Wilt Tospovirus (TSWV) in pepper (Capsicum chinense Jacq.). Eur. J. Plant Pathol. 1998, 104, 489-498. [CrossRef]

62. De Carvalho, L.; Benda, N.; Vaughan, M.; Cabrera, A.; Hung, K.; Cox, T.; Abdo, Z.; Allen, L.; Teal, P. Mi-1-Mediated Nematode Resistance in Tomatoes is Broken by Short-Term Heat Stress but Recovers Over Time. J. Nematol. 2015, 47, $133-140$.

63. Romero, A.M.; Kousik, C.S.; Ritchie, D.F. Temperature Sensitivity of the Hypersensitive Response of Bell Pepper to Xanthomonas axonopodis pv. vesicatoria. Phytopathology 2002, 92, 197-203. [CrossRef] [PubMed]

64. Cai, X.; Takken, F.; Joosten, M.; de Wit, P. Specific recognition of AVR4 and AVR9 results in distinct patterns of hypersensitive cell death in tomato, but similar patterns of defence-related gene expression. Mol. Plant Pathol. 2001, 2, 77-86. [CrossRef] [PubMed]

65. De Jong, C.F.; Takken, F.L.; Cai, X.; de Wit, P.J.; Joosten, M.H. Attenuation of Cf-Mediated Defense Responses at Elevated Temperatures Correlates With a Decrease in Elicitor-Binding Sites. Mol. Plant Microbe Interact. 2002, 15, 1040-1049. [CrossRef]

66. Cheng, C.; Gao, X.; Feng, B.; Sheen, J.; Shan, L.; He, P. Differential temperature operation of plant immune responses. Nat. Commun. 2013, 4, 2530. [CrossRef] [PubMed]

67. Menna, A.; Nguyen, D.; Guttman, D.S.; Desveaux, D. Elevated temperature differentially influences effector-triggered immunity outputs in Arabidopsis. Front. Plant Sci. 2015, 6, 1-7. [CrossRef] [PubMed]

68. Aoun, N.; Tauleigne, L.; Lonjon, F.; Deslandes, L.; Vailleau, F.; Roux, F.; Berthomé, R. Quantitative disease resistance under elevated temperature: Genetic basis of new resistance mechanisms to Ralstonia solanacearum. Front. Plant Sci. 2017, 8, 1387. [CrossRef]

69. Yang, S.; Hua, J. A haplotype-specific Resistance gene regulated by BONZAI1 mediates temperature-dependent growth control in Arabidopsis. Plant Cell 2004, 16, 1060-1071. [CrossRef]

70. Zhu, Y.; Qian, W.; Hua, J. Temperature modulates plant defense responses through NB-LRR proteins. PLoS Pathog. 2010, 6, 1-12. [CrossRef] [PubMed]

71. Mang, H.G.; Qian, W.; Zhu, Y.; Qian, J.; Kang, H.G.; Klessig, D.F.; Hua, J. Abscisic acid deficiency antagonizes high-temperature inhibition of disease resistance through enhancing nuclear accumulation of resistance proteins SNC1 and RPS4 in Arabidopsis. Plant Cell 2012, 24, 1271-1284. [CrossRef] [PubMed]

72. Fesenko, I.; Spechenkova, N.; Mamaeva, A.; Makhotenko, A.V.; Love, A.J.; Kalinina, N.O.; Taliansky, M. Role of the methionine cycle in the temperature-sensitive responses of potato plants to potato virus Y. Mol. Plant Pathol. 2021, 22, 77-91. [CrossRef]

73. Amari, K.; Huang, C.; Heinlein, M. Potential Impact of Global Warming on Virus Propagation in Infected Plants and Agricultural Productivity. Front. Plant Sci. 2021, 12, 649768. [CrossRef]

74. Whitham, S.A.; Yang, C.; Goodin, M.M. Global impact: Elucidating plant responses to viral infection. Mol. Plant Microbe Interact. 2006, 19, 1207-1215. [CrossRef]

75. Lewsey, M.; Palukaitis, P.; Carr, J. Plant-Virus Interactions: Defence and Counter-Defence. In Annual Plant Reviews Volume 34: Molecular Aspects of Plant Disease Resistance; Wiley-Blackwell: Oxford, UK, 2009; pp. 134-176. [CrossRef]

76. Baebler, Š.; Witek, K.; Petek, M.; Stare, K.; Tušek-Žnidarič, M.; Pompe-Novak, M.; Renaut, J.; Szajko, K.; Strzelczyk-Zyta, D.; Marczewski, W.; et al. Salicylic acid is an indispensable component of the Ny-1 resistance-gene-mediated response against Potato virus y infection in potato. J. Exp. Bot. 2014, 65, 1095-1109. [CrossRef]

77. Chandra-Shekara, A.; Navarre, D.; Kachroo, A.; Kang, H.; Klessig, D.; Kachroo, P. Signaling requirements and role of salicylic acid in HRT-And rrt -mediated resistance to turnip crinkle virus in Arabidopsis. Plant J. 2004, 40, 647-659. [CrossRef]

78. Lukan, T.; Baebler, S.; Pompe-Novak, M.; Gucek, K.; Zagoršcak, M.; Coll, A.; Gruden, K. Cell Death Is Not Sufficient for the Restriction of Potato Virus Y Spread in Hypersensitive Response-Conferred Resistance in Potato. Front. Plant Sci. 2018, 9, 1-12. [CrossRef] [PubMed] 
79. Zhao, F.; Yanan, L.; Lijuan, C.; Lisha, Z.; Han, R.; Honghui, L.; Dehui, X. Temperature dependent defence of Nicotiana tabacum against Cucumber mosaic virus and recovery occurs with the formation of dark green islands. J. Plant Biol. 2016, 59, 293301. [CrossRef]

80. Makarova, S.; Makhotenko, A.; Spechenkova, N.; Love, A.J.; Kalinina, N.O.; Taliansky, M. Interactive Responses of Potato (Solanum tuberosum L.) Plants to Heat Stress and Infection With Potato Virus Y. Front. Microbiol. 2018, 9, 1-14. [CrossRef] [PubMed]

81. Chu, M.; Desvoyes, B.; Turina, M.; Noad, R.; Scholthof, H.B. Genetic dissection of tomato bushy stunt virus p19-protein-mediated host-dependent symptom induction and systemic invasion. Virology 2000, 266, 79-87. [CrossRef] [PubMed]

82. Cawly, J.; Cole, A.B.; Király, L.; Qiu, W.; Schoelz, J.E. The plant gene CCD1 selectively blocks cell death during the hypersensitive response to cauliflower mosaic virus infection. Mol. Plant Microbe Interact. 2005, 18, 212-219. [CrossRef] [PubMed]

83. Ishibashi, K.; Masuda, K.; Naito, S.; Meshi, T.; Ishikawa, M. An inhibitor of viral RNA replication is encoded by a plant resistance gene. Proc. Natl. Acad. Sci. USA 2007, 104, 13833-13838. [CrossRef]

84. Komatsu, K.; Hashimoto, M.; Ozeki, J.; Yamaji, Y.; Maejima, K.; Senshu, H.; Himeno, M.; Okano, Y.; Kagiwada, S.; Namba, S. Viral-Induced systemic necrosis in plants involves both programmed cell death and the inhibition of viral multiplication, which are regulated by independent pathways. Mol. Plant Microbe Interact. 2010, 23, 283-293. [CrossRef] [PubMed]

85. Liu, P.P.; Bhattacharjee, S.; Klessig, D.F.; Moffett, P. Systemic acquired resistance is induced by R gene-mediated responses independent of cell death. Mol. Plant Pathol. 2010, 11, 155-160. [CrossRef]

86. Hafez, Y.M.; Bacsó, R.; Király, Z.; Künstler, A.; Király, L. Up-regulation of antioxidants in tobacco by low concentrations of H $2 \mathrm{O} 2$ suppresses necrotic disease symptoms. Phytopathology 2012, 102, 848-856. [CrossRef] [PubMed]

87. Ando, S.; Obinata, A.; Takahashi, H. WRKY70 interacting with RCY1 disease resistance protein is required for resistance to Cucumber mosaic virus in Arabidopsis thaliana. Physiol. Mol. Plant Pathol. 2014, 85, 8-14. [CrossRef]

88. Harris, J.M.; Balint-kurti, P.; Bede, J.C.; Day, B.; Gold, S.; Goss, E.M.; Grenville-briggs, L.J.; Jones, K.M.; Wang, A.; Wang, Y.; et al. What are the Top 10 Unanswered Questions in Molecular Plant-Microbe Interactions? Mol. Plant Microbe Interact. 2020, X, 1-12. [CrossRef]

89. Zheng, C.; Chen, P.; Gergerich, R. Characterization of Resistance to Soybean mosaic virus in Diverse Soybean Germplasm. Crop Sci. 2005, 45, 2503-2509. [CrossRef]

90. Meziadi, C.; (IPS2, Orsay, France). Personal communication, 2021.

91. Vallejos, C.E.; Astua-monge, G.; Jones, V.; Plyler, T.R.; Sakiyama, N.S.; Mackenzie, S.A. Genetic and Molecular Characterization of the I Locus of Phaseolus vulgaris. Genetics 2006, 172, 1229-1242. [CrossRef]

92. Nodari, R.O.; Tsai, S.M.; Gilbertson, R.L.; Gepts, P. Towards an integrated linkage map of common bean. 2. Development of an RFLP-based linkage map. Theor. Appl. Genet. 1993, 85, 513-520. [CrossRef] [PubMed]

93. Kyle, M.M.; Provvidenti, R. Inheritance of resistance to potato y viruses in Phaseolus vulgaris L: 1 . Two independent genes for resistance to watermelon mosaic virus-2. Theor. Appl. Genet. 1987, 74, 595-600. [CrossRef]

94. Provvidenti, R. Inheritance of resistance to watermelon mosaic virus 2 in Phaseolus vulgaris. Phytopathology 1974, 64, 14481450. [CrossRef]

95. Provvidenti, R.; Gonsalves, D.; Taiwo, M.A. Inheritance of resistance to Blackeye cowpea mosaic and Cowpea aphid-borne mosaic viruses in Phaseolus vulgaris. J. Hered. 1983, 74, 60-61. [CrossRef]

96. Provvidenti, R.; Gonsalves, D.; Ranalli, P. Inheritance of resistance to soybean mosaic virus in Phaseolus vulgaris. J. Hered. 1982, 73, 302-303. [CrossRef]

97. Kyle, M.M.; Provvidenti, R. Inheritance of resistance to potyviruses in Phaseolus vulgaris L. 2. Linkage relations and utility of a dominant gene for lethal systemic necrosis to Soybean mosaic virus. Theor. Appl. Genet. 1993, 86, 189-196. [CrossRef]

98. Provvidenti, R.; Chirco, E.M. Inheritance of resistance to peanut mottle virus in Phaseolus vulgaris. J. Hered. 1987, 78, 402-403.

99. Li, R.H.; Zettler, F.W.; Elliott, M.S.; Petersen, M.A.; Still, P.E.; Baker, C.A.; Mink, G.I. A strain of Peanut Mottle Virus Seedborne in Bambarra Groundnut. Plant Dis. 1991, 75, 130-133. [CrossRef]

100. Fisher, M.L.; Kyle, M.M. Inheritance of resistance to potyviruses in Phaseolus vulgaris L. III. Cosegregation of phenotypically similar dominant responses to nine potyviruses. Theor. Appl. Genet. 1994, 89, 818-823. [CrossRef] [PubMed]

101. Hart, J.P.; Griffiths, P.D. Genotyping-by-Sequencing Enabled Mapping and Marker Development for the By-2 Potyvirus Resistance Allele in Common Bean. Plant Genome 2015, 8, 1-14. [CrossRef] [PubMed]

102. Dickson, M.H.; Natti, J.J. Inheritance of resistance of Phaseolus vulgaris to bean yellow mosaic virus. Phytopathology 1968, $58,1450$.

103. Bello, M.H.; Moghaddam, S.M.; Massoudi, M.; Mcclean, P.E.; Cregan, P.B.; Miklas, P.N. Application of in silico bulked segregant analysis for rapid development of markers linked to Bean common mosaic virus resistance in common bean. BMC Genom. 2014, 15, 1-13. [CrossRef]

104. Chung, B.N.; Canto, T.; Tenllado, F.; Choi, K.S.; Joa, J.H.; Ahn, J.J.; Kim, C.H.; Do, K.S. The effects of high temperature on infection by Potato virus Y, Potato virus A, and Potato leafroll virus. Plant Pathol. J. 2016, 32, 321-328. [CrossRef]

105. Aguilar, E.; Allende, L.; Del Toro, F.J.; Chung, B.N.; Canto, T.; Tenllado, F. Effects of elevated CO2 and temperature on pathogenicity determinants and virulence of potato virus X/Potyvirus-Associated synergism. Mol. Plant-Microbe Interact. 2015, 28, 1364-1373. [CrossRef]

106. Szittya, G.; Silhavy, D.; Molnar, A.; Havelda, Z.; Lovas, A.; Lakatos, L.; Banfaldi, Z.; Burgyan, J. Low temperature inhibits RNA silencing-mediated defence by the control of siRNA generation. EMBO J. 2003, 22, 633-640. [CrossRef] [PubMed] 
107. Raza, A.; Razzaq, A.; Mehmood, S.S.; Zou, X.; Zhang, X.; Lv, Y.; Xu, J. Impact of Climate Change on Crops Adaptation and Strategies to Tackle Its Outcome: A Review. Plants 2019, 8, 34. [CrossRef] [PubMed]

108. Del Toro, F.; Rakhshandehroo, F.; Larruy, B.; Aguilar, E.; Tenllado, F.; Canto, T. Effects of simultaneously elevated temperature and $\mathrm{CO} 2$ levels on Nicotiana benthamiana and its infection by different positive-sense RNA viruses are cumulative and virus type-specific. Virology 2017, 511, 184-192. [CrossRef] [PubMed]

109. Chung, B.N.; Koh, S.W.; Choi, K.S.; Joa, J.H.; Kim, C.H.; Selvakumar, G. Temperature and CO2 Level Influence Potato leafroll virus Infection in Solanum tuberosum. Plant Pathol. J. 2017, 33, 522-527. [CrossRef]

110. Aguilar, E.; del Toro, F.J.; Figueira-Galán, D.; Hou, W.; Canto, T.; Tenllado, F. Virus infection induces resistance to Pseudomonas syringae and to drought in both compatible and incompatible bacteria-Host interactions, which are compromised under conditions of elevated temperature and CO2 levels. J. Gen. Virol. 2020, 101, 122-135. [CrossRef] [PubMed] 